\title{
A preliminary fish survey of the estuaries on the southeast coast of South Africa, Kayser's Beach - Kei Mouth: a comparative study
}

\author{
NC James ${ }^{1 *}$ and TD Harrison ${ }^{2,1}$ \\ 'South African Institute for Aquatic Biodiversity, Private Bag 1015, Grahamstown, 6140, South Africa \\ ${ }^{2}$ Marine Division, Department of the Environment (Northern Ireland), 17 Antrim Rd, Tonagh, Lisburn, BT28 3AL, Northern Ireland
}

\begin{abstract}
A basic ichthyofaunal and physico-chemical survey of estuaries on the southeast coast of South Africa from Kayser's Beach to Kei Mouth was undertaken during September and October 1996. Twenty-eight (28) estuaries have been identified along this stretch of coastline, and these were grouped into three types: small $(<10 \mathrm{ha})$ predominantly closed estuaries, moderate to large ( $>10 \mathrm{ha}$ ) predominantly closed estuaries, and predominantly open estuaries. Multivariate analyses revealed significant differences between estuarine types both in terms of their physico-chemical characteristics and fish communities. These features were consistent with those reported in other parts of the south and southeast coast. Overall, predominantly closed estuaries had a lower species diversity than predominantly open estuaries and smaller systems had a lower species diversity than moderate to large systems. Although differences were observed between estuarine types, most systems provided important habitat for a number of estuarine-dependent marine species as well as resident species, which were often recorded in high numbers. Many of these species were also endemic, which further emphasises the importance of these estuaries in maintaining ichthyofaunal diversity in the region. This survey represents one of the few fish surveys undertaken along this little-studied section of coastline.
\end{abstract}

Keywords: ichthyofauna, estuarine survey, fish habitat, southeast coast

\section{INTRODUCTION}

Warm-temperate estuaries constitute important nursery areas for a number of estuarine-associated fish species (e.g. Potter and Hyndes, 1999; James et al., 2007a). Despite the importance of these systems as nursery areas, habitat degradation, hydrological manipulations, overexploitation and pollution increasingly threaten these systems (Whitfield and Cowley, 2010). In order to understand change in estuaries and maintain their ecological function, basic information is needed on fish assemblages. This information is often lacking, particularly for estuaries on the southeast coast of South Africa, around East London. Although studies have been carried out on the biology of the Nahoon (Steinke, 1986; Campbell et al., 2001; Bursey and Wooldridge, 2002; 2003; Sale, 2007; Geldenhuys, 2013), Nyara (Perisinotto et al., 2000, Walker et al., 2001), Goda (Vumazonke et al., 2008) and Haga Haga (Whitfield, 1992) estuaries, no information exists on fish biodiversity for the majority of systems along this coastline. There have only been two studies conducted which have focused of fish: one on recruitment of ichthyoplankton into the Haga Haga Estuary (Whitfield, 1992) and one on the feeding dynamics of four species in the Goda Estuary (Vumazonke et al., 2008). As part of a national assessment of South African estuaries, a fish survey was undertaken along the southeast coastline between Kayser's Beach and Kei Mouth; basic physico-chemical variables, fish community data and a comparative analysis are provided.

\section{STUDY AREA}

The Eastern Cape region falls within a transitional area of climatic zones and experiences relatively mild summers and

\footnotetext{
* To whom all correspondence should be addressed. e-mail:n.james@saiab.ac.za

Received: 17 February 2015; accepted in revised form 18 November 2015
}

winters (Kopke, 1988; Stone et al., 1998). Seasonality of rainfall is less pronounced than in other parts of the country (Stone et al., 1998) and, although rainfall may occur at any time of the year, it usually displays an autumn/spring bimodal pattern with peak rainfall in spring (Kopke, 1988). The coastline is influenced by the south-flowing Agulhas Current (Shannon, 1989; Heydorn, 1991). Being tropical in origin, the waters of this current are relatively warm; however, as it flows south it tends to cool with inshore water temperatures along the Eastern Cape coast varying between 14 and $20^{\circ} \mathrm{C}$ (Day, 1981). The section of coastline between Kayser's Beach and Kei Mouth extends some $68 \mathrm{~km}$ and is intersected by 31 river outlets (Fig. 1). The city of East London is the major metropolitan area situated on this coast.

\section{MATERIALS AND METHODS}

The estuaries between Kayser's Beach and Kei Mouth were sampled between September and October 1996. Each system was sampled once and took 1-3 days to survey, depending on the size of the system.

\section{Physico-chemical}

During each survey, selected physico-chemical parameters were measured at various sites within each system ranging from the mouth area (Site 1) upstream; the number of sites varied depending on the size of each system. Water depth and transparency were measured using a $20 \mathrm{~cm}$ diameter Secchi disc attached to a weighted shot line graduated at $10 \mathrm{~cm}$ intervals. Temperature $\left({ }^{\circ} \mathrm{C}\right)$, salinity (psu), $\mathrm{pH}$, dissolved oxygen $\left(\mathrm{mg} \cdot \mathrm{L}^{-1}\right)$, and turbidity (NTU) were measured using a Horiba U-10 Water Quality Checker. Where water depth permitted (usually $>0.5 \mathrm{~m}$ ), both surface and bottom waters were measured. The mouth state of each system at the time of sampling was also noted. 


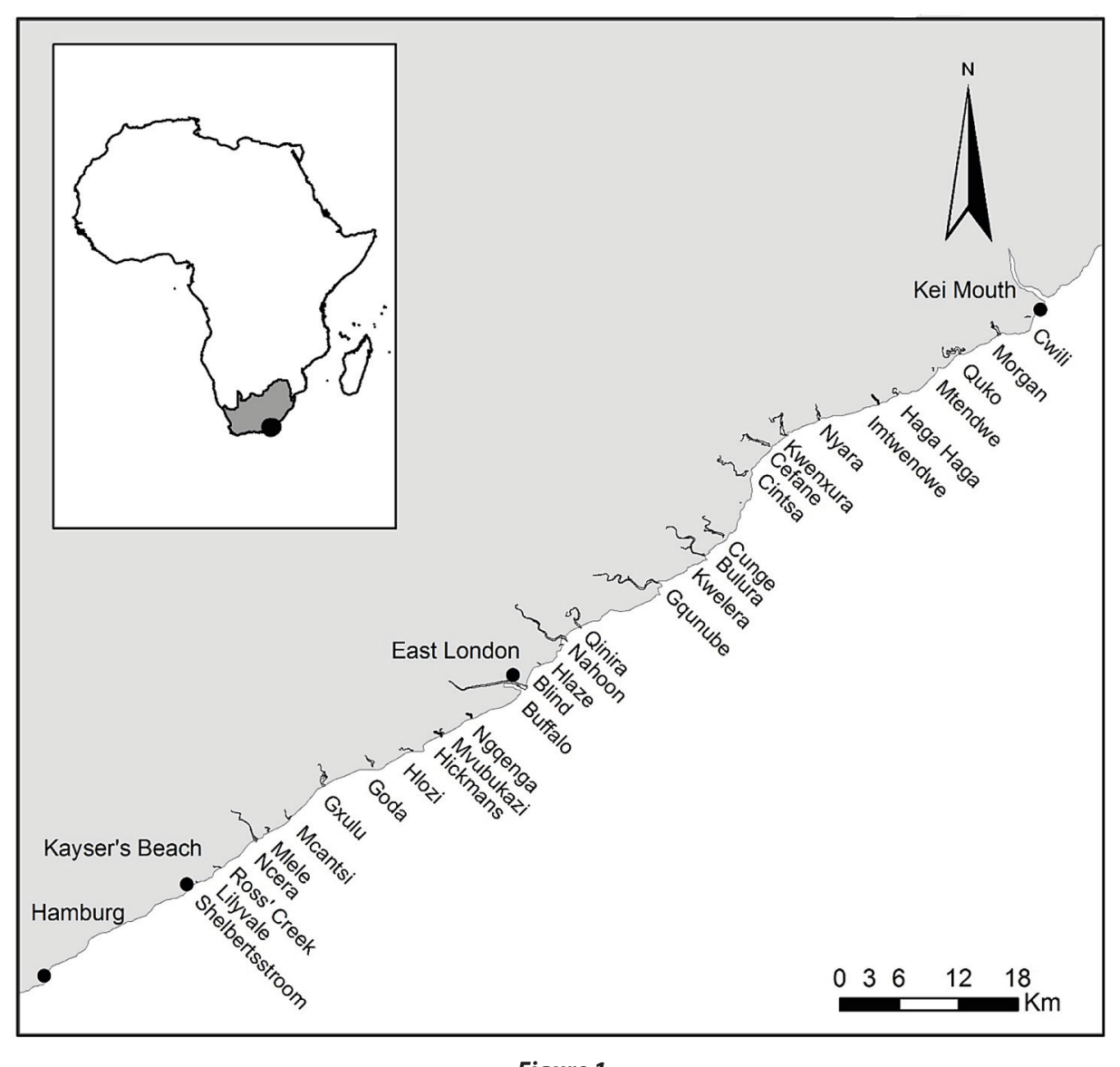

Figure 1

Coastal outlets between Kayser's Beach and Kei Mouth on the southeast coast of South Africa

\section{Ichthyofauna}

The ichthyofauna of each estuary was sampled using a $30 \mathrm{~m}$ long x $1.7 \mathrm{~m}$ deep x $15 \mathrm{~mm}$ bar mesh seine net fitted with a $5 \mathrm{~mm}$ bar mesh purse, and a fleet of multi-mesh gill nets. The gill nets were either $10 \mathrm{~m}$ or $20 \mathrm{~m}$ in length and $1.7 \mathrm{~m}$ in depth and consisted of three equal sections of $45 \mathrm{~mm}, 75 \mathrm{~mm}$ and $100 \mathrm{~mm}$ stretch meshes. Seine netting was carried out during daylight hours in shallow ( $<1.5 \mathrm{~m}$ deep), unobstructed areas with gently sloping banks. Fish caught were identified and measured to the nearest millimetre standard length (SL) before being released. Where large catches of a species were made, a sub-sample was kept and returned to the laboratory where the fish were identified, measured and weighed to the nearest $1.0 \mathrm{~g}$; specimens that could not be identified in the field were also kept and processed in the laboratory. All fishes were identified by reference to Smith and Heemstra (1991) and Skelton (1993); taxonomic identities of certain species were adjusted using information provided in Heemstra and Heemstra (2004). The total fish species composition, by number and mass, was calculated for each system. The relative biomass contribution of each species was calculated using actual recorded masses as well as masses derived from length-mass relationships provided in Harrison (2001).

\section{Estuary classification}

Estuaries were divided into two main groups on the basis of predominant mouth condition, according to the classification given in Harrison and Whitfield (2006). The two main groups were predominantly open estuaries and predominantly closed estuaries. Predominantly closed estuaries were further subdivided into two groups based on surface area: small closed estuaries with a surface area below 10 ha and moderate to large closed estuaries with a surface area above 10 ha.

\section{Multivariate analyses}

Data were analysed using the Plymouth Routines in Multivariate Ecological Research (PRIMER) package (version 6.0). A principal component analysis (PCA) was undertaken on the overall mean (surface and bottom) values of the physicochemical variables recorded in each system. Each parameter was first examined for normality; only turbidity required logtransformation $(\ln [1+x])$. The data were also examined for any inter-correlations (Pearson $r$ ); $\mathrm{pH}$ exhibited significant correlations $(p<0.05)$ with both dissolved oxygen and temperature and was omitted from the analysis. Although salinity and depth also showed a significant correlation, these parameters were retained. A PCA was performed based on the following normalised parameters: depth, temperature, salinity, dissolved oxygen, and turbidity. An analysis of similarities (ANOSIM) was also undertaken (using the normalised Euclidean distance similarity measure) to test for significant differences between estuarine types. Estuaries sampled during the latter part of the survey (Kwenxura - Cwili) were sampled following heavy rainfall in their catchments, which led to breaching of the mouths of closed estuaries, reduced salinities in some cases, and elevated turbidities. These estuaries were excluded from the ANOSIM test. 
Fish catch data were subject to non-metric multidimensional scaling (MDS) ordination. Specimens not identified to species level (e.g. Mugilidae) as well as exotic species (e.g. Micropterus spp.) were excluded from the analysis. Abundance and biomass data were first standardised and then square-root transformed before calculating a Bray-Curtis similarity matrix. Standardisation removed the effect of variable sampling while transformation scales down the importance of dominant species (Field et al., 1982; Clarke and Warwick, 2001). An ANOSIM test was applied to both the abundance and biomass data to examine differences in fish communities between estuary types. Obvious outliers identified in the MDS plots were omitted from the ANOSIM test. A similarity percentages analyses (SIMPER) was also undertaken to identify species that characterise estuary types as well as those that discriminate between estuary types.

\section{RESULTS}

A total of 31 systems were sampled between Kayser's Beach and Kei Mouth. Three systems, (Imtwendwe, Mvubukazi, and Ngqenga) comprised small coastal streams and were not considered further. Of the remaining systems, 5 were predominantly open estuaries and 23 were predominantly closed estuaries - 13 estuaries were small closed systems and 10 were moderate to large closed estuaries.

\section{Physico-chemical}

\section{Small predominantly closed estuaries}

Of the 13 small predominantly closed estuaries, 7 were open to the sea at the time of sampling. Systems such as the Haga-Haga, Mtendwe, and Cwili had all breached as a result of high river flows following heavy rainfall in their catchments. The outlets in the other systems appeared to have formed as a result of the lowering of the barrier at the mouth by wave action. All estuaries were relatively shallow, with average water depths generally not exceeding $1.0 \mathrm{~m}$ (Table 1). Water temperatures averaged between $17.8^{\circ} \mathrm{C}$ (Blind) and $24.6^{\circ} \mathrm{C}$ (Cunge). Mean salinities ranged from almost fresh (0.3) recorded in the Mtendwe to 27.7 recorded in the Hlozi. Salinities were fairly uniform throughout most of the systems with no clear horizontal or vertical gradients. Only the Hlozi and Hlaze estuaries exhibited a horizontal decrease in salinity of more than 1.0 , while a marked vertical salinity gradient was only evident in the Cunge and Cwili estuaries. Average dissolved oxygen values ranged between $3.4 \mathrm{mg} \cdot \mathrm{L}^{-1}$ (Mtendwe) and $11.8 \mathrm{mg} \cdot \mathrm{L}^{-1}$ (Shelbertsstroom), with most systems exceeding $7.0 \mathrm{mg} \cdot \mathrm{L}^{-1}$. Mean turbidity values ranged from 3.5 NTU (Hlozi and Hlaze) to 36.2 NTU (Cwili); relatively high ( $>33 \mathrm{NTU}$ ) average turbidities were recorded in the Haga-Haga, Mtendwe and Cwili systems, a result of heavy rainfall in their catchments. Average $\mathrm{pH}$ values (7.5-8.1) in all estuaries were characteristic of seawater (Table 1). Physicochemical parameters by site are given in Table A1 (Appendix 1).

\section{Moderate to large predominantly closed estuaries}

Three (Kwenxura, Nyara, and Morgan) of the ten moderate to large predominantly closed estuaries were open to the sea at the time of this survey; high river flows following heavy rainfall in their catchments resulted in these estuaries breaching. Apart from those estuaries that had recently breached, mean water depths generally exceeded $1.0 \mathrm{~m}$ (Table 1$)$. Water temperatures averaged between $19.0^{\circ} \mathrm{C}$ (Nyara) and $23.8^{\circ} \mathrm{C}$ (Cintsa). Water

\begin{tabular}{|c|c|c|c|c|c|c|c|}
\hline \multicolumn{8}{|c|}{ 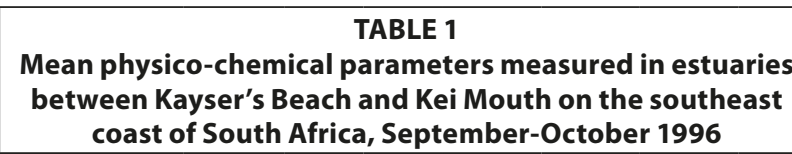 } \\
\hline Estuary & Mouth & $\begin{array}{l}\text { Depth } \\
\text { (m) }\end{array}$ & $\begin{array}{c}\text { Temp. } \\
\left({ }^{\circ} \mathrm{C}\right)\end{array}$ & Salinity & \begin{tabular}{|c|} 
Diss. \\
oxygen \\
$\left(\mathrm{mg}^{-\mathrm{L}^{-1}}\right)$
\end{tabular} & $\begin{array}{l}\text { Turbid. } \\
\text { (NTU) }\end{array}$ & $\mathrm{pH}$ \\
\hline \multicolumn{8}{|c|}{ Small closed estuaries } \\
\hline Shelbertsstroom & Closed & 1 & 19.8 & 6.8 & 11.8 & 6.6 & 8.1 \\
\hline Lilyvale & Closed & 0.8 & 21 & 17.6 & 9.4 & 21.6 & 8 \\
\hline Ross' Creek & Closed & 0.6 & 18.9 & 6.6 & 6.6 & 20 & 7.8 \\
\hline Mlele & Closed & 1.1 & 19.8 & 15.3 & 7.5 & 16 & 7.8 \\
\hline Mcantsi & Open & 1 & 23 & 14.1 & 7 & 7 & 7.9 \\
\hline Hlozi & Closed & 1.3 & 20.2 & 27.7 & 7.3 & 3.5 & 7.7 \\
\hline Hickmans & Closed & 1.6 & 22 & 18.8 & 6.4 & 5.2 & 7.5 \\
\hline Blind & Open & 0.2 & 17.8 & 0.8 & 8.9 & 19 & 7.9 \\
\hline Hlaze & Open & 0.5 & 21.5 & 23 & 9.3 & 3.5 & 8 \\
\hline Cunge & Closed & 0.5 & 24.6 & 18.6 & 7.4 & 4 & 7.7 \\
\hline Haga-Haga & Open & 0.5 & 21.3 & 25.8 & 8 & 33.7 & 7.7 \\
\hline Mtendwe & Open & 0.8 & 21.8 & 0.3 & 3.4 & 33.5 & 7.8 \\
\hline Cwili & Open & 0.8 & 20.6 & 16.6 & 7.7 & 36.2 & 7.8 \\
\hline \multicolumn{8}{|c|}{ Moderate to large closed estuaries } \\
\hline Ncera & Closed & 1.2 & 20.5 & 33.7 & 7.7 & 2.4 & 7.9 \\
\hline Gxulu & Closed & 1.4 & 22.1 & 29.6 & 6.4 & 3.9 & 7.8 \\
\hline Goda & Closed & 2 & 21 & 32.6 & 6.1 & 6.2 & 7.8 \\
\hline Qinira & Closed & 1.7 & 21.5 & 28 & 6.4 & 4.8 & 7.7 \\
\hline Bulura & Closed & 1.2 & 22.9 & 29.2 & 7.5 & 4 & 7.9 \\
\hline Cintsa & Closed & 1.4 & 23.8 & 31.1 & 5.5 & 3.4 & 7.5 \\
\hline Cefane & Closed & 0.9 & 23.5 & 28.9 & 5 & 7.1 & 7.6 \\
\hline Kwenxura & Open & 0.8 & 19.7 & 29.1 & 7 & 34.6 & 7.9 \\
\hline Nyara & Open & 0.6 & 19 & 21.8 & 3.5 & 73.3 & 7.9 \\
\hline Morgan & Open & 0.6 & 22 & 8.6 & 8.4 & 103.7 & 7.6 \\
\hline \multicolumn{8}{|c|}{ Permanently open estuaries } \\
\hline Buffalo & Open & 3.4 & 18.2 & 31.2 & 7.8 & 12.8 & 7.9 \\
\hline Nahoon & Open & 2.3 & 19.4 & 32.6 & 8.4 & 5.9 & 7.9 \\
\hline Gqunube & Open & 1.7 & 20 & 32.8 & 6.8 & 17.4 & 7.9 \\
\hline Kwelera & Open & 1.6 & 21 & 32.1 & 6.8 & 18.8 & 7.7 \\
\hline Quko & Open & 1.5 & 20.7 & 10.4 & 8.3 & 265 & 7.7 \\
\hline
\end{tabular}

temperatures generally increased from the lower to the upper reaches of the estuaries; there was very little vertical temperature stratification. Mean salinities ranged from 8.6 (Morgan) to 33.7 (Ncera) with values generally exceeding 21.0. Salinities were fairly uniform in most systems with no clear horizontal or vertical gradients. A pronounced axial salinity gradient, however, was present in the Nyara and Morgan estuaries with salinities decreasing upstream from the mouth; this is a result of high freshwater inflow following rainfall in the catchment. Mean dissolved oxygen values ranged from $3.5 \mathrm{mg} \cdot \mathrm{L}^{-1}$ (Nyara) to $8.4 \mathrm{mg} \cdot \mathrm{L}^{-1}$ (Morgan) with most values exceeding $5.0 \mathrm{mg} \cdot \mathrm{L}^{-1}$. 
Most of the estuaries were fairly clear, with average turbidities not exceeding 10 NTU. Only the Kwenxura, Nyara and Morgan estuaries were turbid, averaging between 34.6 and 103.7 NTU; this is a result of turbid freshwater inflow following rains in their catchments. Mean $\mathrm{pH}$ values ranged from 7.5 to 7.9 (Table 1). Physico-chemical parameters by site are given in Table A2 (Appendix 1).

\section{Predominantly open estuaries}

Mean water depths recorded in the five predominantly open estuaries ranged from $3.4 \mathrm{~m}$ (Buffalo) to $1.5 \mathrm{~m}$ (Quko) (Table 1). Water temperatures averaged between $18.2^{\circ} \mathrm{C}$ (Buffalo) and $21.0^{\circ} \mathrm{C}$ (Kwelera). Generally, water temperatures increased upstream from the mouth in most systems; a marked vertical gradient was also recorded in the Buffalo with surface temperatures being warmer than those near the bottom. Mean salinities in most estuaries exceeded 31.0, with very little horizontal or vertical salinity variation. In contrast, surface salinities in the Quko decreased from 19.3 in the lower reaches to 0.0 in the upper reaches, while bottom salinities decreased from 31.5 to 0.0 . This was as a result of freshwater inflows following rainfall in the catchment. Mean dissolved oxygen values ranged between 6.8 and $8.4 \mathrm{mg} \cdot \mathrm{L}^{-1}$. Most estuaries were clear, with mean turbidities of between 5.9 and 18.8 NTU. A high (265.0 NTU) mean turbidity was recorded in the Quko and this was due to turbid freshwater inflows following heavy rainfall in the catchment. The mean $\mathrm{pH}$ in all estuaries was similar to seawater (7.7-7.9) (Table 1). Physico-chemical parameters by site are given in Table A3 (Appendix 1).

\section{Multivariate analysis}

The PCA classification (Fig. 2) divided the estuaries based on depth, salinity and turbidity (Axis 1) and temperature and dissolved oxygen (Axis 2). The first two axes accounted for approximately $63 \%$ of the variation between the samples. Those turbid systems from the Kwenxura northward situated toward the right of the plot (Fig. 2). The remaining systems showed a gradation from small predominantly closed estuaries toward the right of the plot to moderate to large systems, situated toward the left of the plot; predominantly open estuaries were located toward the upper left of the plot (Fig. 2). The ANOSIM test revealed that estuarine types to the south of the Kwenxura were significantly different (global $R=0.32 ; p<0.05$ ).

\section{Fish communities}

\section{Small predominantly closed estuaries}

A total of 26 species were captured in small predominantly closed estuaries with between 5 (Hlaze) and 17 (Cwili) species captured per estuary. Numerically important species captured within this group of estuaries were Gilchristella aestuaria $($ mean $=30.4 \%)$, Rhabdosargus holubi $($ mean $=$ 22.3\%), Myxus capensis (mean =14.2\%), Mugil cephalus $($ mean $=9.7 \%)$, Atherina breviceps (mean $=7.1 \%)$, Liza richardsonii (mean $=4.1 \%)$, Glossogobius callidus $($ mean $=2.3 \%)$, juvenile mugilids (mean $=2.1 \%)$, Monodactylus falciformis $($ mean $=1.1 \%)$ and Liza tricuspidens $($ mean $=1.0 \%)($ Table 2, Appendix 1: Table A4). Although present in most systems,

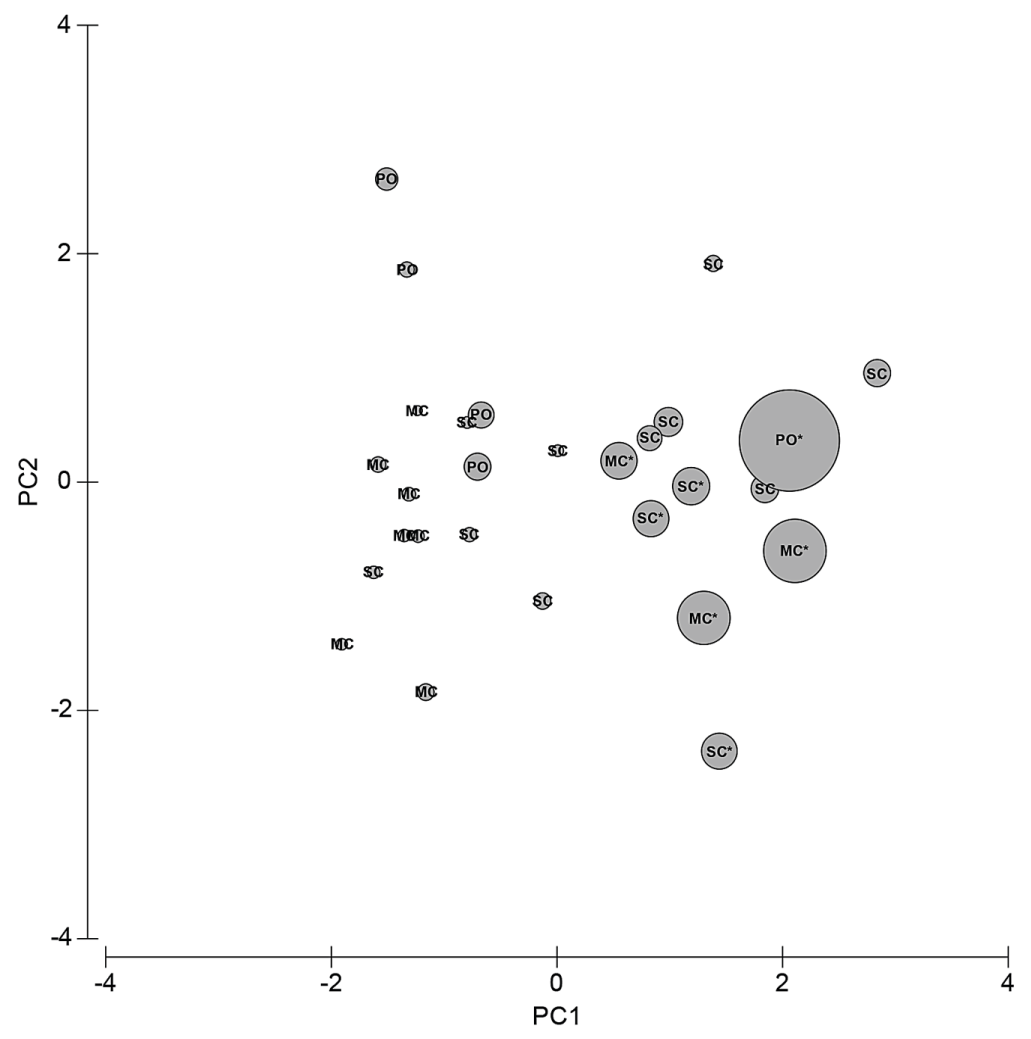

Figure 2

PCA ordination of physico-chemical variables measured in estuaries between Kayser's Beach and Kei Mouth on the southeast coast of South Africa (SC $=$ small closed estuaries, $M C=$ moderate to large closed estuaries, $P O=$ predominantly open estuaries). Bubble plots represent the relative mean turbidity recorded in each system; systems marked with an asterisk (*) indicate estuaries from the Kwenxura northward, which were surveyed following heavy rainfall. 


\begin{tabular}{|c|c|c|c|}
\hline \multicolumn{4}{|c|}{$\begin{array}{c}\text { TABLE } 2 \\
\text { Mean numerical abundance (\%) of fishes captured in small } \\
\text { closed, moderate to large closed and permanently open } \\
\text { estuaries between Kayser's Beach and Kei Mouth on the } \\
\text { southeast coast of South Africa, September-October } 1996\end{array}$} \\
\hline Species & $\begin{array}{l}\text { Small } \\
\text { closed }\end{array}$ & $\begin{array}{l}\text { Mod. to large } \\
\text { closed }\end{array}$ & $\begin{array}{l}\text { Perm. } \\
\text { open }\end{array}$ \\
\hline Acanthopagrus berda & 0.03 & 0 & 0.26 \\
\hline Ambassis gymnocephalus & 0 & 0.00 & 1.16 \\
\hline Ambassis productus & 0 & 0 & 0.04 \\
\hline Amblyrhynchotes honckenii & 0 & 2.07 & 0.02 \\
\hline Antennarias striatus & 0 & 0 & 0.02 \\
\hline Argyrosomus japonicus & 0.01 & 0.25 & 0.60 \\
\hline Atherina breviceps & 7.05 & 13.12 & 3.56 \\
\hline Caffrogobius gilchristi & 0.11 & 0.25 & 4.33 \\
\hline Caffrogobius nudiceps & 0.01 & 0 & 0.78 \\
\hline Clinus superciliosus & 0 & 0 & 0.04 \\
\hline Dasyatis kuhlii & 0 & 0 & 0.02 \\
\hline Diplodus cervinus & 0 & 0 & 0.04 \\
\hline Diplodus sargus & 0.06 & 7.20 & 0.61 \\
\hline Elops machnata & 0 & 0.01 & 0.48 \\
\hline Eugomphodus taurus & 0 & 0 & 0.06 \\
\hline Gaelichthys feliceps & 0 & 0.04 & 0.44 \\
\hline Gambusia affinis & 0.01 & 0 & 0 \\
\hline Gilchristella aestuaria & 30.38 & 30.87 & 48.96 \\
\hline Glossogobius callidus & 2.25 & 3.29 & 2.89 \\
\hline Hemiramphus far & 0 & 0 & 0.76 \\
\hline Heteromycteris capensis & 0.02 & 0.04 & 0.33 \\
\hline Lichia amia & 0 & 0.08 & 0.14 \\
\hline Lithognathus lithognathus & 0.16 & 0.13 & 0.48 \\
\hline Liza alata & 0.05 & 0 & 0 \\
\hline Liza dumerilii & 0.60 & 4.30 & 6.09 \\
\hline Liza macrolepis & 0.41 & 0.35 & 0.14 \\
\hline Liza richardsonii & 4.13 & 4.00 & 2.07 \\
\hline Liza tricuspidens & 0.97 & 1.80 & 1.68 \\
\hline Micropterus punctulatus & 0 & 0.01 & 0 \\
\hline Micropterus salmoides & 0.01 & 0.10 & 0 \\
\hline Monodactylus falciformis & 1.06 & 0.38 & 0.30 \\
\hline Mugil cephalus & 9.65 & 0.52 & 4.42 \\
\hline Mugilidae & 2.06 & 0.54 & 2.30 \\
\hline Myliobatis aquila & 0 & 0 & 0.25 \\
\hline Myxus capensis & 14.18 & 5.32 & 0.66 \\
\hline Oligolepis keiensis & 0 & 0.01 & 0 \\
\hline Oreochromis mossambicus & 0.45 & 1.44 & 0 \\
\hline Parablennius lodosus & 0 & 0.00 & 0 \\
\hline Platycephalus indicus & 0 & 0 & 2.02 \\
\hline Pomadasys commersonnii & 0.07 & 0.38 & 0.97 \\
\hline Pomadasys olivaceum & 0 & 0 & 1.61 \\
\hline Pomatomus saltatrix & 0 & 0.06 & 0.27 \\
\hline Psammogobius knysnaensis & 0.08 & 1.87 & 1.48 \\
\hline Raja miraletus & 0 & 0 & 0.02 \\
\hline Rhabdosargus globiceps & 0 & 5.10 & 0 \\
\hline Rhabdosargus holubi & 22.26 & 16.33 & 16.37 \\
\hline Rhabdosargus sarba & 0 & 0.01 & 0 \\
\hline Sarpa salpa & 0.02 & 0.03 & 0.13 \\
\hline Solea turbynei & 3.88 & 0.08 & 0.42 \\
\hline Syngnathus acus & 0 & 0 & 0.04 \\
\hline Torpedo fuscumaculata & 0 & 0 & 0.02 \\
\hline Torpedo sinuspersici & 0 & 0 & 0.02 \\
\hline Valamugil buchanani & 0 & 0.01 & 0.10 \\
\hline Valamugil robustus & 0 & 0 & 0.08 \\
\hline Number of species & 26 & 34 & 44 \\
\hline
\end{tabular}

\begin{tabular}{|c|c|c|c|}
\hline \multicolumn{4}{|c|}{$\begin{array}{c}\text { TABLE } 3 \\
\text { Mean biomass (\%) of fishes captured in small closed, moderate } \\
\text { to large closed and permanently open estuaries between } \\
\text { Kayser's Beach and Kei Mouth on the southeast coast of } \\
\text { South Africa, September-October } 1996\end{array}$} \\
\hline Species & $\begin{array}{l}\text { Small } \\
\text { closed }\end{array}$ & $\begin{array}{l}\text { Mod. to large } \\
\text { closed }\end{array}$ & $\begin{array}{l}\text { Perm. } \\
\text { open }\end{array}$ \\
\hline Acanthopagrus berda & 0.06 & 0 & 1.92 \\
\hline Ambassis gymnocephalus & 0 & 0.00 & 0.07 \\
\hline Ambassis productus & 0 & 0.01 & 0.01 \\
\hline Amblyrhynchotes honckenii & 0 & 9.22 & 0.02 \\
\hline Antennarias striatus & 0 & 0 & 0.00 \\
\hline Argyrosomus japonicus & 1.65 & 0 & 10.79 \\
\hline Atherina breviceps & 0.56 & 0.84 & 0.20 \\
\hline Caffrogobius gilchristi & 0.02 & 0.06 & 0.21 \\
\hline Caffrogobius nudiceps & 0.00 & 0 & 0.03 \\
\hline Clinus superciliosus & 0 & 0 & 0.00 \\
\hline Dasyatis kuhlii & 0 & 0 & 3.97 \\
\hline Diplodus cervinus & 0 & 0 & 0.00 \\
\hline Diplodus sargus & 0.00 & 0.06 & 0.01 \\
\hline Elops machnata & 0 & 0.48 & 28.58 \\
\hline Eugomphodus taurus & 0 & 0 & 14.25 \\
\hline Gaelichthys feliceps & 0 & 1.21 & 8.69 \\
\hline Gambusia affinis & 0.00 & 0 & 0 \\
\hline Gilchristella aestuaria & 4.39 & 1.71 & 1.21 \\
\hline Glossogobius callidus & 0.35 & 0.47 & 0.19 \\
\hline Hemiramphus far & 0 & 0 & 0.04 \\
\hline Heteromycteris capensis & 0.01 & 0.01 & 0.01 \\
\hline Lichia amia & 0 & 3.97 & 7.14 \\
\hline Lithognathus lithognathus & 2.57 & 0.55 & 1.62 \\
\hline Liza alata & 3.32 & 0 & 0 \\
\hline Liza dumerilii & 3.66 & 9.73 & 7.10 \\
\hline Liza macrolepis & 0.79 & 0.84 & 0.21 \\
\hline Liza richardsonii & 11.80 & 25.69 & 7.55 \\
\hline Liza tricuspidens & 5.19 & 12.21 & 8.23 \\
\hline Micropterus punctulatus & 0 & 0.00 & 0 \\
\hline Micropterus salmoides & 0.38 & 0.06 & 0 \\
\hline Monodactylus falciformis & 1.63 & 0.37 & 0.69 \\
\hline Mugil cephalus & 24.07 & 3.01 & 3.35 \\
\hline Mugilidae & 0.20 & 0.01 & 0.01 \\
\hline Myliobatis aquila & 0 & 0 & 1.36 \\
\hline Myxus capensis & 10.75 & 6.16 & 0.21 \\
\hline Oligolepis keiensis & 0 & 0.00 & 0 \\
\hline Oreochromis mossambicus & 8.82 & 8.55 & 0 \\
\hline Parablennius lodosus & 0 & 0.00 & 0 \\
\hline Platycephalus indicus & 0 & 0 & 0.73 \\
\hline Pomadasys commersonnii & 0.62 & 5.54 & 1.87 \\
\hline Pomadasys olivaceum & 0 & 0 & 0.12 \\
\hline Pomatomus saltatrix & 0 & 1.11 & 3.99 \\
\hline Psammogobius knysnaensis & 0.05 & 0.09 & 0.02 \\
\hline Raja miraletus & 0 & 0 & 0.02 \\
\hline Rhabdosargus globiceps & 0 & 0.53 & 0 \\
\hline Rhabdosargus holubi & 19.12 & 8.05 & 6.46 \\
\hline Rhabdosargus sarba & 0 & 0.75 & 0 \\
\hline Sarpa salpa & 0.00 & 0.00 & 0.66 \\
\hline Solea turbynei & 0.01 & 0.03 & 0.03 \\
\hline Syngnathus acus & 0 & 0 & 0.00 \\
\hline Torpedo fuscumaculata & 0 & 0 & 0.45 \\
\hline Torpedo sinuspersici & 0 & 0 & 0.06 \\
\hline Valamugil buchanani & 0 & 0.44 & 2.94 \\
\hline Valamugil robustus & 0 & 0 & 0.01 \\
\hline Number of species & 26 & 34 & 44 \\
\hline
\end{tabular}


species such as A. breviceps, G. aestuaria, and G. callidus were not captured in either the Blind or Hlaze estuaries.

In terms of biomass, important species included M. cephalus $($ mean $=24.1 \%), R$. holubi $($ mean $=19.1 \%)$, L. richardsonii $($ mean $=11.8 \%), M$. capensis $($ mean $=10.8 \%)$, Oreochromis mossambicus (mean $=8.8 \%)$, L. tricuspidens (mean $=5.2 \%)$, G. aestuaria $($ mean $=4.4 \%)$, Liza dumerili (mean $=3.7 \%)$, Lithognathus lithognathus $($ mean $=2.6 \%)$, and M. falciformis (mean =1.6\%) (Table 3, Appendix 1: Table A5). Species such as Argyrosomus japonicus (mean =1.7\%) was only recorded in the Haga-Haga, while Liza alata (mean $=3.3 \%$ ) was only captured in the Shelbertsstroom and Blind estuaries.

\section{Moderate to large predominantly closed estuaries}

A total of 34 species were captured in moderate to large predominantly closed estuaries with between 14 (Nyara) and 21 (Gxulu and Goda) species captured per estuary. The most abundant species within this group of estuaries overall were G. aestuaria $($ mean $=30.9 \%), R$. holubi $($ mean $=16.3 \%)$, A. breviceps $($ mean $=13.1 \%)$, Diplodus capensis $($ mean $=7.2 \%)$, M. capensis $($ mean $=5.3 \%)$, L. dumerili $($ mean $=4.3 \%)$, L. richardsonii $($ mean $=4.0 \%)$, G. callidus $($ mean $=3.3 \%)$, L. tricuspidens $($ mean $=1.8 \%)$, and O. mossambicus $($ mean $=1.4 \%)($ Table 2, Appendix 1: Table A6) .

Dominant species overall in terms of biomass included L. richardsonii $($ mean $=25.7 \%)$, L tricuspidens $($ mean $=12.2 \%)$, L. dumerili $($ mean $=9.7 \%)$, A. japonicus $($ mean $=9.2 \%), R$. holubi (mean $=8.6 \%)$, O. mossambicus $($ mean $=6.8 \%)$, M. capensis (mean $=6.2 \%)$, Pomadasys commersonnii $($ mean $=5.5 \%)$, Lichia amia $($ mean $=4.0 \%)$, M. cephalus $($ mean $=3.0 \%)$, G. aestuaria (mean $=1.7 \%)$, Gaelichthys feliceps $($ mean $=1.2 \%)$ and Pomatomus saltatrix $($ mean $=1.1 \%)($ Table 3, Appendix 1: Table A7).

\section{Predominantly open estuaries}

A total of 44 species were captured in the predominantly open estuaries with between 21 (Quko) and 35 (Kwelera) species captured per estuary. In terms of numbers, catches were dominated by G. aestuaria $($ mean $=49.0 \%)$, R. holubi (mean $=16.4 \%)$, L. dumerili $($ mean $=6.1 \%)$, Caffrogobius gilchristi $($ mean $=4.3 \%)$, M. cephalus $($ mean $=3.5 \%)$, A. breviceps $($ mean $=2.9 \%)$, G. callidus $($ mean $=2.3 \%)$, juvenile mugilids (mean $=2.3 \%)$, L. richardsonii $($ mean $=2.1 \%)$, L. tricuspidens $($ mean $=1.7 \%)$, Psammogobius knysnaensis $($ mean $=1.5 \%)$, and Pomadasys olivaceus $($ mean $=1.3 \%)$. (Table 2, Appendix 1: Table A8). The fish species mass in predominantly open estuaries was dominated by E. machnata $($ mean $=28.6 \%), A$. japonicus $($ mean $=10.8 \%)$, L. tricuspidens $($ mean $=8.2 \%)$, L. richardsonii $($ mean $=7.6 \%)$, L. dumerili (mean $=7.1 \%)$, G. feliceps $($ mean $=7.0 \%), R$. holubi $($ mean $=6.5 \%)$, Lichia amia $($ mean $=5.7 \%)$, M. cephalus $($ mean $=2.7 \%)$, P. saltatrix $($ mean $=2.4 \%)$, Valamugil buchanani $($ mean $=2.4 \%)$, L. lithognathus $($ mean $=1.6 \%)$, P. commersonnii $($ mean $=1.5 \%)$, and G. aestuaria $($ mean $=1.2 \%)($ Table 3 , Appendix 1: Table A9). Carcharias taurus (mean $=2.9 \%$ ) was only recorded in the Nahoon estuary.

\section{Multivariate analyses}

The MDS based on abundance data produced a pattern where two small closed systems (Blind and Hlaze) were situated as distinct outliers to the right of the plot; the remaining systems formed a gradation from small closed estuaries situated in the centre of the plot to medium to large closed estuaries and predominantly open systems toward the left of the ordination (Fig. 3a). In terms of biomass, one small closed system (Mtendwe) was situated as an outlier at the bottom right of the ordination; the remaining systems formed a gradation from small closed estuaries situated toward the top centre of the plot to moderate to large closed estuaries and predominantly open estuaries located toward the bottom left of the ordination (Fig. 3b).

The ANOSIM test (excluding the Blind, Hlaze and Mtendwe estuaries) based on abundance data revealed significant differences between estuary types (global $R=0.34 ; p<0.01$ ). Predominantly open systems were the most distinct group with $R$-values of between 0.44 and 0.62 ; small and moderate to large predominantly closed estuaries were also different from one another, although differences were not as distinct $(R=0.16)$. Biomass data yielded a similar result showing all estuary types as distinct (global $R=0.57 ; p<0.01$ ). Predominantly open systems were also the most distinct group with $R$-values of between 0.65 and 0.86 ; small and moderate to large predominantly closed estuaries were also distinct, although differences were not as great $(R=0.41)$.
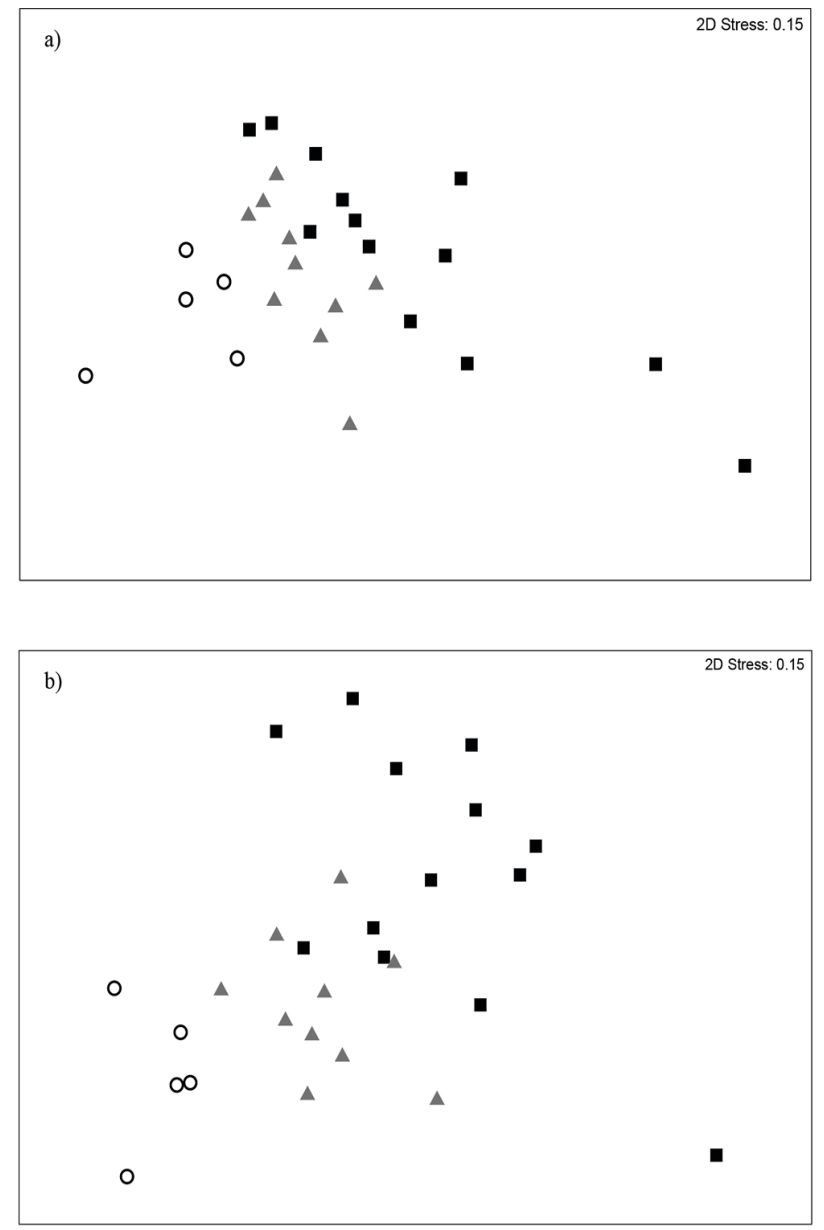

Figure 3

MDS ordination of fish communities in estuaries between Kayser's Beach and Kei Mouth on the southeast coast of South Africa based on (a) abundance and (b) biomass data ( $\mathbf{\square}=$ small closed estuaries, $\boldsymbol{\Delta}=$ moderate to large closed estuaries, $\mathbf{O}=$ predominantly open estuaries) 
SIMPER analysis based on abundance determined that small and moderate to large predominantly closed estuaries had an average dissimilarity of $36.9 \%$. Species such as M. falciformis, M. cephalus, M. capensis, and R. holubi, which accounted for $10.2 \%$ of the dissimilarity, were more abundant in small closed systems, while species such as A. breviceps, D. capensis, G. aestuaria, G. callidus, L. dumerili, L. tricuspidens and O. mossambicus (which collectively accounted for $17.2 \%$ of the dissimilarity) were more abundant in moderate to large closed estuaries. Based on biomass these estuary types had an average dissimilarity of $48.7 \%$. Gilchristella aestuaria, L. lithognathus, M. falciformis, M. cephalus, M. capensis, O. mossambicus, and R. holubi accounted for $19.2 \%$ of the dissimilarity and comprised a greater proportion of biomass catch in small closed estuaries; A. japonicus, L. amia, L. dumerili, L. richardsonii, L. tricuspidens, and P. commersonnii (which accounted for $20.4 \%$ of the dissimilarity) comprised a greater proportion of the biomass catch in moderate to large closed estuaries.

Predominantly closed small estuaries and predominantly open estuaries had an average dissimilarity of $46.5 \%$ based on abundance data. Species such as A. breviceps, L. richardsonii, M. flaciformis, M. cephalus, M. capensis, O. mossambicus, and R. holubi comprised $16.4 \%$ of the dissimilarity and comprised a greater proportion of the abundance catch in small closed estuaries. Argyrosomus japonicus, C. gilchristi, E. machnata, G. aestuaria, G. callidus, L. dumerili, L. tricuspidens, P. commersonnii, and P. knysnaensis contributed $18.2 \%$ to the dissimilarity and were more abundant in predominantly open estuaries. In terms of biomass, small closed estuaries and predominantly open estuaries had an average dissimilarity of $62.8 \%$; G. aestuaria, L. lithognathus, L. richardsonii,

M. falciformis, M. cephalus, M. capensis, O. mossambicus, and $R$. holubi contributed $22.6 \%$ to the dissimilarity and comprised a greater proportion of the biomass catch in small closed estuaries. Argyrosomus japonicus, E. machnata, G. feliceps, L. amia, L. dumerili, L. tricuspidens, P. commersonnii, P. saltatrix, and V. buchanani contributed $30.3 \%$ to the average dissimilarity and comprised a greater proportion of the catch in predominantly open estuaries.

Average dissimilarities, based on abundance, between moderate to large predominantly closed estuaries and predominantly open estuaries measured $39.9 \%$. Atherina breviceps, G. callidus, L. richardsonii, L. tricuspidens, M. capensis, O. mossambicus, and R. holubi contributed $15.3 \%$ to the dissimilarity and comprised a greater proportion of the catch in moderate to large closed estuaries. Species such as C. gilchristi, E. machnata, G. aestuaria, L. dumerili, M. cephalus, P. commersonnii, P. olivaceus, and $P$. knysnaensis contributed $13.8 \%$ to the dissimilarity and were numerically more important in predominantly open estuaries. In terms of biomass, moderate to large closed estuaries and predominantly open estuaries had an average dissimilarity of $49.8 \%$. Atherina breviceps, $G$. aestuaria, $L$. dumerili, $L$. richardsonii, $L$. tricuspidens, $M$. capensis, O. mossambicus, P. commersonnii, and R. holubi contributed $19.2 \%$ to the dissimilarity and comprised a greater proportion of the biomass catch in moderate to large closed estuaries. Species such as A. japonicus, E. machnata, G. feliceps, L. amia, L. lithognathus, P. saltatrix, and $V$. buchanani contributed $20.5 \%$ to the dissimilarity and comprised a greater proportion of the biomass catch in predominantly open estuaries.

\section{DISCUSSION}

Although this survey represents a single temporal snapshot of estuaries along the East London and surrounding coastline, it does provide a preliminary understanding of estuarine fish communities in a poorly studied section of our coastline. Some 31 coastal outlets were included in this survey (Fig. 1); three systems, however, (Imtwendwe, Mvubukazi, and Ngqenga) were very small coastal streams and probably serve little or no function for estuarine-associated fishes. The majority of estuaries along this coastline are predominantly closed systems that are isolated from the sea for varying periods by the formation of a sand barrier at the mouth; 13 estuaries are small $(<10 \mathrm{ha})$ closed estuaries while 10 are moderate to large ( $>10 \mathrm{ha}$ ) predominantly closed estuaries. The remaining 5 estuaries are predominantly open estuaries, where river flow and/or tidal currents are sufficient to maintain a connection with the sea.

Closed warm-temperate estuaries usually breach during periods of high fluvial discharge, particularly after rainfall in the catchment (Perissinotto et al., 2000; Cowley and Whitfield, 2001). All closed estuaries from the Kwenxura northward were open at the time of this survey and this was a result of heavy rainfall and runoff in their catchments. A similar situation was noted during surveys of south coast estuaries as well as in the Nyara estuary where mouth breaching had occurred following rains in the catchment (Perissinotto et al., 2000; James and Harrison, 2009). Breaching can also occur as a result of high seas overtopping and lowering the sand bar to a point that allows an outlet to form. The outlets at the Blind and Hlaze estuaries during this survey were probably created by this process. Unlike closed estuaries, river flow and/or tidal currents act to maintain a connection with the sea in predominantly open systems (Cooper, 2001).

Rainfall and runoff in estuaries from the Kwenxura northward was also responsible for high turbidities recorded in these estuaries ( $>33 \mathrm{NTU}$ ) and this accounted for their relatively distinct location in the PCA plot (Fig. 2). The remaining systems showed a gradation from small closed estuaries toward to moderate to large systems and to predominantly open estuaries. The ANOSIM test also revealed that these estuarine types were distinct. Small closed estuaries were typically shallow (mostly $<1.0 \mathrm{~m}$ ) systems with mesohaline $(5-18)$ to polyhaline (18-30) salinities; mean water temperatures ranged between 19 and $25^{\circ} \mathrm{C}$ and the waters were relatively clear (mostly $<20$ NTU). Because of their small catchments, mouth opening events due to rainfall and runoff are likely to be relatively shortlived, limiting tidal intrusion of seawater. Seawater, however, may also enter these systems via barrier overwash which would raise salinities. Moderate to large closed estuaries were generally deeper (mostly $>1.0 \mathrm{~m}$ ) systems with clear (mostly $<10$ NTU), polyhaline conditions prevailing; mean water temperatures were between 20 and $24^{\circ} \mathrm{C}$. The higher salinities may be a result of longer periods of mouth opening when they breach and thus more seawater exchange; these systems are also often formed behind long barriers, which probably enables more seawater to enter these systems via waves overtopping the barrier during high seas. Predominantly open estuaries were fairly deep systems $(>1.5 \mathrm{~m})$ and were characterised by euhaline ( $>30)$ salinities and low turbidities $(<20 \mathrm{NTU})$; temperatures were also generally lower (mean $18-21^{\circ} \mathrm{C}$ ) than closed estuaries. These conditions are a reflection of the predominantly open mouth condition, which enables clear, cooler, seawater to penetrate these systems. Similar conditions were also reported 
from comparable surveys on the south and southeast coast (Harrison, 1999; Vorwerk et al., 2001; James and Harrison, 2008; 2009; 2010a; 2010b; 2011). Small closed estuaries were typically shallow $(<1.0 \mathrm{~m})$ systems with oligohaline $(0.5-5.0)$ to polyhaline salinities while moderate to large estuaries were deeper systems (mostly $>1.0 \mathrm{~m}$ ) with mainly mesohaline to polyhaline salinities; predominantly open estuaries were relatively deep (mostly $>1.5 \mathrm{~m}$ ) and were mostly polyhaline to euhaline. This suggests that similar hydrological and morphological processes operate within each broad estuarine type and this is reflected in their physico-chemical conditions.

High rainfall and runoff in estuaries from the Kwenxura northward resulted in these estuaries grouping separately in the PCA plot based on physico-chemical variables, and a fairly mixed clustering of all estuaries. Multivariate analyses based on fish communities showed that the various estuarine types contained somewhat distinct fish communities, irrespective of the anomalous physico-chemical conditions encountered in the northern estuaries. A total of 26 species were captured in small predominantly closed estuaries with between 5 and 17 species per system. Overall, dominant species numerically and/or by biomass included A. breviceps, G. aestuaria, G. callidus, L. lithognathus, L. dumerili, L. richardsonii, L. tricuspidens, M. falciformis, M. cephalus, M. capensis, O. mossambicus, and R. holubi. A total of 34 species were captured in moderate to large closed estuaries; important species within this group of estuaries overall were A. japonicus, A. breviceps, D. capensis, G. feliceps, G. aestuaria, G. callidus, L. amia, L. dumerili, L. richardsonii, L. tricuspidens, M. cephalus, $M$. capensis, O. mossambicus, P. commersonnii, $P$. saltatrix, and $R$. holubi. The highest numbers of species (44 in total) were captured in predominantly open estuaries. Catches were dominated by A. japonicus, A. breviceps, C. gilchristi, E. machnata, G. feliceps, G. aestuaria, G. callidus, L. amia, L. lithognathus, L. dumerili, L. richardsonii, L. tricuspidens, M. cephalus, $P$. commersonnii, P. olivaceus, $P$. saltatrix, $P$. knysnaensis, $R$. holubi, and $V$. buchanani.

Similar species were found to dominate the fish catches of south and southeast Cape coast estuaries; species such as A. breviceps, G. aestuaria, G. callidus, L. lithognathus, L. dumerili, L. richardsonii, $M$. falciformis, M. cephalus, M. capensis, O. mossambicus, P. knysnaensis, and R. holubi were among the dominant taxa in small predominantly closed estuaries (Harrison, 1999; Vorwerk et al., 2001; James and Harrison, 2008; 2009; 2010a; 2010b; 2011). Dominant species in moderate to large predominantly closed estuaries included A. japonicus, A. breviceps, C. gilchristi, E. machnata, G. aestuaria, G. callidus, H. capensis, L. amia, L. lithognathus, L. dumerili, L. richardsonii, L. tricuspidens, M. falciformis, M. cephalus, M. capensis, O. mossambicus, P. commersonnii, $P$. knysnaensis, and R. holubi. Predominantly open estuaries were dominated by A. japonicus, A. breviceps, C. gilchristi, C. natalensis, C. nudiceps, Clinus superciliosus, D. capensis, E. machnata, G. feliceps, G. aestuaria, G. callidus, L. amia, L. lithognathus, L. dumerili, L. richardsonii, L. tricuspidens, M. falciformis, M. cephalus, $M$. capensis, P. commersonnii, $P$. knysnaensis, Rhabdosargus globiceps, $R$. holubi, Sarpa salpa, Solea turbynei, and V. buchanani (Harrison, 1999; Vorwerk et al., 2001; James and Harrison, 2008; 2009; 2010a; 2010b; 2011).

Predominantly open estuaries had a higher species richness (mean $=28$ species) than both small closed estuaries $($ mean $=12)$ and moderate to large closed estuaries $($ mean $=19$ species). A similar pattern has been described by other workers where open estuaries were found to contain more species than closed systems (e.g. Bennett, 1989; Whitfield and Kok, 1992, Vorwerk et al., 2003; Harrison and Whitfield, 2006). The higher species richness in predominantly open estuaries is often attributed to an increase in the number of marine-spawning species (particularly marine stragglers) in permanently open estuaries (Bennett, 1989). Marine stragglers, which are mainly stenohaline species and not dependent on estuaries, are virtually absent from predominantly closed estuaries (Harrison, 2003). In this study, marine stragglers were only found in predominantly open estuaries and included Amblyrhynchotes honckenii, Antennarias striatus, Dasyatis kuhlii, Diplodus cervinus, C. taurus, Myliobatis aquila, P. olivaceus, and Raja miraletus (Table $2 \& 3$ ). These species, however, did not contribute appreciably to the dissimilarity between predominantly open systems and predominantly closed estuaries.

Marine migrant species, which depend on estuaries during part of their life cycle and estuarine resident species were the main groups that accounted for the differences between these estuary types. Vorwerk et al. (2003) also found significant differences between the fish assemblages of permanently open estuaries and intermittently open (closed) estuaries on the Eastern Cape coast between Port Alfred and Hamburg and that the taxa that accounted for these differences were primarily estuarine resident and marine migrant species. During this study, marine migrant species such as A. japonicus, E. machnata, G. feliceps, L. amia, L. lithognathus, L. dumerili, L. tricuspidens, P. saltatrix, and V. buchanani contributed toward the dissimilarity between predominantly open estuaries and predominantly closed systems and generally comprised a greater proportion of the abundance and/or biomass catch in predominantly open systems. This is probably a result of yearround access of these species to predominantly open estuaries and limited recruitment opportunities in closed systems (Vorwerk et al., 2003). Estuarine species such as C. gilchristi and $P$. knysnaensis also contributed to the dissimilarity between predominantly open systems and closed estuaries and were found to be more abundant in predominantly open estuaries. These species are reported to prefer the sandy lower reaches of open estuaries and are also thought to have marine breeding populations (Whitfield, 1998).

Some marine migrant species, such as L. richardsonii, M. falciformis, M. capensis, and R. holubi, which also accounted for the dissimilarity between predominantly open estuaries and predominantly closed systems, comprised a greater proportion of the abundance/biomass catch in closed estuaries. Vorwerk et al. (2003) also found that species such as M. falciformis and $R$. holubi occurred in higher proportions in closed estuaries than in open systems. Many estuarine-dependent marine species have been shown to be able to recruit into closed estuaries during bar overwash events (Cowley et al., 2001; Kemp and Froneman, 2004; Vivier and Cyrus, 2001; James et al., 2007b). This recruitment strategy probably accounts for the relative importance of these species in predominantly closed estuaries. Estuarine resident species such as A. breviceps and G. callidus also contributed toward the dissimilarity between these estuarine types and comprised a greater proportion of the abundance/biomass captured in predominantly closed estuaries relative to predominantly open systems. A similar situation was reported by Vorwerk et al. (2003) where resident species such as A. breviceps and G. callidus represented a greater proportion of the catch in temporarily open/closed estuaries compared with permanently open systems; they also accounted for a large degree of the dissimilarity between these systems. Short-lived estuarine resident species are well adapted 
to the estuarine environment and can dominate the fish communities of estuaries numerically (Potter et al., 1990). The freshwater species $O$. mossambicus also contributed toward the dissimilarity between predominantly open estuaries and closed systems and comprised a greater proportion of the abundance/ biomass catch in closed estuaries. Oreochromis mossambicus is sometimes abundant in coastal lakes and predominantly closed estuaries but is usually absent from permanently open estuaries (Whitfield and Blaber, 1979).

Dissimilarities between predominantly open estuaries and closed systems were also due to some species comprising a higher proportion of the abundance in open systems but being more important in closed systems in terms of biomass. These included the estuarine species G. aestuaria and the marine migrant species $M$. cephalus and P. commersonnii. Vorwerk et al. (2003) also found that G. aestuaria dominated the catches in permanently open estuaries but contributed less to the catch in temporarily open/closed estuaries. While recruitment of marine migrant species into closed estuaries may take place via barrier overwash, migration back to the marine environment can only occur when a connection is formed with the sea following mouth breaching. The high biomass contribution of marine migrant species in closed estuaries may be a result of these species being trapped in these systems for extended periods and the energy obtained from feeding put into growth (Vorwerk et al., 2001).

Multivariate analyses also showed differences in the fish communities of small predominantly closed estuaries and moderate to large closed estuaries. Species richness was higher in the moderate to large closed estuaries than in small closed estuaries. Marine migrant species such as M. falciformis, M. cephalus, M. capensis, and R. holubi contributed toward the dissimilarity between these systems and comprised a greater proportion of the abundance and biomass catch in small estuaries. All these species are able to tolerate prolonged periods of isolation from the sea and reduced salinities (Whitfield, 1998).

Several marine migrant species that accounted for some of the dissimilarity between predominantly open estuaries and closed systems also accounted for the dissimilarity between moderate to large closed estuaries and small closed estuaries. Species such as A. japonicus, G. feliceps, L. amia, L. dumerili, L. richardsonii, L. tricuspidens, $P$. commersonnii, and $P$. saltatrix comprised a greater percentage of the abundance and/or biomass in moderate to large closed estuaries relative to small closed systems. The estuarine resident species $A$. breviceps and G. callidus were also more important in moderate to large closed estuaries. Dissimilarities between moderate to large closed estuaries and small closed estuaries was also due to species such as G. aestuaria and O. mossambicus comprising a higher proportion of the abundance in moderate to large closed systems but being more important in small closed estuaries in terms of biomass. The absence of these species also accounted for the small closed Blind and Hlaze estuaries being identified as outliers in the MDS ordination. Both the Blind and Hlaze estuaries are heavily modified systems that fall within the East London city area. The absence of any freshwater or estuarine resident species in these estuaries is probably an indication of the poor water quality in these systems; resident taxa are most susceptible to degradation of estuaries as they are entirely dependent on estuaries.

Vorwerk et al. (2003) demonstrated significant differences between the fish assemblages in smaller $(<5 \mathrm{ha})$ and larger ( $>15$ ha) temporarily open/closed estuaries between Port Alfred and Hamburg. Small closed estuaries had a much lower species richness and density than larger closed estuaries. In addition, marine migrant species that accounted for the separation between these estuaries were similar to those responsible for the dissimilarity between permanently open estuaries and temporarily open/closed systems. These differences were attributed to a much weaker recruitment response in the smaller estuaries as a result of much lower water volumes entering the sea during mouth opening events (Vorwerk et al., 2003). Large closed estuaries have higher nutrient input, positive salinity gradients and, more importantly, are open for longer periods. Prolonged closed phases in small estuaries (which also have lower habitat diversity) result in a low recruitment potential for juvenile marine fish and effectively prevent the emigration of adults back to sea. In addition, during a prolonged closed phase, salinity may either decrease due to freshwater input or increase due to evaporation, allowing only strongly euryhaline species to tolerate these conditions (Vorwerk et al., 2003).

This survey represents one of the few fish surveys undertaken along this section of coastline. The estuarine types identified were found to be distinctive both in terms of their physicochemical characteristics and fish communities and these were consistent with those reported in other parts of the south and southeast Cape coast (e.g. Harrison, 1999; Vorwerk et al., 2001; James and Harrison, 2008; 2009; 2010a; 2010b; 2011). These differences are primarily a result of predominant mouth condition and estuary size (Vorwerk et al., 2001; Harrison and Whitfield, 2006). However, both permanently open estuaries and predominantly closed systems along this section of the coastline were found to support a number of estuarine-dependent marine species as well as resident species. It should also be noted that many of the dominant species recorded during this survey are endemic species, which further emphasises the importance of these estuaries in maintaining the ichthyofaunal diversity in the region.

\section{REFERENCES}

BENNETT BA (1989) A comparison of the fish communities in nearby permanently open, seasonally open and normally closed estuaries in the south-western Cape, South Africa. S. Afr. J. Mar. Sci. 8 43-55. http://dx.doi.org/10.2989/02577618909504550

BURSEY ML and WOOLDRIDGE TH (2002) Diversity of benthic macrofauna of the flood-tidal delta of the Nahoon Estuary and adjacent beach, South Africa. Afr. Zool. 37 231-246.

BURSEY ML and WOOLDRIDGE TH (2003) Physical factors regulating macrobenthic community structure on a South African estuarine flood-tidal delta. Afr. J. Mar. Sci. 25 263-274. http://dx.doi. org/10.2989/18142320309504015

CAMPBELL EE, KNOOP WT and BATE GC (1991) A comparison of phytoplankton biomass and primary production in three East Cape estuaries, South Africa. S. Afr. J. Sci. 87 259-264.

CLARKE KR and WARWICK RM (2001) Change in Marine Communities: An Approach to Statistical Analysis and Interpretation. PRIMER-E, Plymouth.

COOPER JAG (2001) Geomorphological variability among mic rotidal estuaries from the wave-dominated South African coast. Geomorphology 40 99-122. http://dx.doi.org/10.1016/ S0169-555X(01)00039-3

COWLEY PD and WHITFIELD, AK (2001) Ichthyofaunal characteristics of a typical temporarily open/closed estuary on the southeast coast of South Africa. Ichthyol. Bull. JLB Smith Inst. Ichthyol. 71 1-19.

COWLEY PD, WHITFIELD AK and BELL KNI (2001) The surf zone ichthyoplankton adjacent to an intermittently open estuary, with evidence of recruitment during marine overwash events. Estuar. Coast. ShelfSci. 52 339-348. http://dx.doi.org/10.1006/ecss.2000.0710

DAY JH (1981) Summaries of current knowledge of 43 estuaries in southern Africa. In: Day JH (ed.) Estuarine Ecology with Particular 
Reference to Southern Africa. AA Balkema, Cape Town.

FIELD JG, CLARKE KR and WARWICK RM (1982) A practical strategy for analysing multispecies distribution patterns. Mar. Ecol. Prog. Ser. 8 37-52. http://dx.doi.org/10.3354/meps008037

GELDENHUYS C (2013) Mangrove and salt marsh dynamics at Nahoon Estuary, Eastern Cape: a planted mangrove forest. MSc thesis, Rhodes University.

HARRISON TD (1999) A preliminary survey of the estuaries on the south coast of South Africa, Cape Agulhas - Cape St Blaize, with particular reference to the fish fauna. Trans. R. Soc. S. Afr. 54 285-310. http://dx.doi.org/10.1080/00359199909520629

HARRISON TD (2001) Length-weight relationships of fishes from South African estuaries. J. Appl. Ichthyol. 17 46-48. http://dx.doi. org/10.1046/j.1439-0426.2001.00277.x

HARRISON TD (2003) Biogeography and community structure of fishes in South African estuaries. PhD thesis, Rhodes University.

HARRISON TD and WHITFIELD AK (2006) Estuarine typology and the structuring of fish communities in South Africa. Environ. Biol. Fishes 75 269-293. http://dx.doi.org/10.1007/s10641-006-0028-y

HEEMSTRA P and HEEMSTRA E (2004) Coastal Fishes of Southern Africa. NISC, Grahamstown. 488 pp.

HEYDORN AEF (1991) The conservation status of southern African estuaries. In: Huntley BJ (ed.) Biotic Diversity in Southern Africa. Concepts and Conservation. Oxford University Press, Cape Town.

JAMES NC and HARRISON TD (2008) A preliminary survey of the estuaries on the south coast of South Africa, Cape St Blaize, Mossel Bay - Robberg Peninsula, Plettenberg Bay, with particular reference to the fish fauna. Trans. R. Soc. S. Afr. 63 111-127. http://dx.doi. org/10.1080/00359190809519216

JAMES NC and HARRISON TD (2009) A preliminary survey of the estuaries on the south coast of South Africa, Robberg Peninsula Cape St Francis, with particular reference to the fish fauna Trans. R. Soc. S. Afr. 6414-31.

JAMES NC and HARRISON TD (2010a) A preliminary survey of the estuaries on the southeast coast of South Africa, Cape St Francis Cape Padrone, with particular reference to the fish fauna Trans. $R$. Soc. S. Afr. 65 69-84. http://dx.doi.org/10.1080/00359191003652116

JAMES NC and HARRISON TD (2010b) A preliminary survey of the estuaries on the southeast coast of South Africa, Cape Padrone - Great Fish River, with particular reference to the fish fauna Trans. R. Soc. S. Afr. 65 149-164. http://dx.doi. org/10.1080/00359191003652165

JAMES NC and HARRISON TD (2011) A preliminary survey of the estuaries on the southeast coast of South Africa, Old Woman's Tyolomnqa, with particular reference to the fish fauna Trans. R. Soc. S. Afr. 66 59-77. http://dx.doi.org/10.1080/00359 19X.2011.580018

JAMES NC, WHITFIELD AK, COWLEY PD and LAMBERTH S (2007a) Fish communities in temporarily open/closed estuaries from the warm- and cool-temperate regions of South Africa - A review. Rev. Fish Biol. Fish. 17 565-580. http://dx.doi.org/10.1007/ s11160-007-9057-7

JAMES NC, COWLEY PD and WHITFIELD AK (2007b) Abundance, recruitment and residency of two sparids in an intermittently open estuary in South Africa. Afr. J. Mar. Sci. 29 527-538. http://dx.doi. org/10.2989/AJMS.2007.29.3.18.348

KEMP JOG and FRONEMAN PW (2004) Recruitment of ichthyoplankton and macroplankton during overtopping events into a temporarily open/closed southern African estuary. Estuar. Coast. Shelf Sci. 61 529-537. http://dx.doi.org/10.1016/j.ecss.2004.06.016

KOPKE D (1988) The climate of the Eastern Cape. In: Bruton MN and Gess FW (eds) Towards an Environmental Plan for the Eastern Cape. Rhodes University, Grahamstown.

PERISSINOTTO R, WALKER DR, WEBB P, WOOLDRIDGE TH and BALLY R (2000) Relationships between zoo- and phytoplankton in a warm-temperate, semi-permanently closed estuary, South Africa. Estuar. Coast. Shelf Sci. 51 1-11. http://dx.doi.org/10.1006/ ecss. 2000.0613

POTTER IC and HYNDES GA (1999) Characteristics of the ichthyofaunas of the southwestern Australian estuaries, including comparisons with Holarctic estuaries and estuaries elsewhere in temperate Australia: A review. Aust. J. Ecol. 24 395-421. http:// dx.doi.org/10.1046/j.1442-9993.1999.00980.x

POTTER IC, BECKLEY LE, WHITFIELD AK and LENANTON RCJ (1990) Comparisons between the roles played by estuaries in the life cycles of fishes in temperate western Australia and southern Africa. Environ. Biol. Fishes 28 143-178. http://dx.doi.org/10.1007/ BF00751033

SALE MC (2007) The value of freshwater inflows into the Kowie, Kromme and Nahoon estuaries. MCom thesis, Nelson Mandela Metropolitan University.

SHANNON LV (1989) The physical environment. In: Payne AL and Crawford RJM (eds) Oceans of life off Southern Africa. Vlaeberg Publishers, Johannesburg.

SKELTON PH (1993) A Complete Guide to the Freshwater Fishes of Southern Africa. Southern Book Publishers, Halfway House. 388 pp.

SMITH MM and HEEMSTRA PC (1991) Smiths' Sea Fishes. Southern Book Publishers, Johannesburg. 1048 pp.

STEINKE TD (1986) Mangroves of the East London area. The Naturalist 30 50-53.

STONE AW, WEAVER AB and WEST WO (1998) Climate and Weather. In: Lubke R and de Moor I (eds) A Field Guide to the Eastern and Southern Cape Coasts. University of Cape Town Press, Cape Town.

VIVIER L and CYRUS DP (2001) Juvenile fish recruitment through wave-overtopping into a closed subtropical estuary. Afr. J. Aquat. Sci. 26 109-113. http://dx.doi.org/10.2989/16085910109503731

VORWERK PD, WHITFIELD AK, COWLEY PD and PATERSON AW (2001) A survey of selected Eastern Cape estuaries with particular reference to the ichthyofauna. Ichthyol. Bull. JLB Smith Inst. Ichthyol. 72 1-52.

VORWERK PD, WHITFIELD AK, COWLEY PD and PATERSON AW (2003) The influence of selected environmental variables on fish assemblage structure in a range of southeast African estuaries. Environ. Biol. Fishes 66 237-247. http://dx.doi. org/10.1023/A:1023922521835

VUMAZONKE LU, MAINOANE TS, BUSHULA T and PAKHOMOV EA (2008) A preliminary investigation of winter daily food intake by four small teleost fish species from the Igoda Estuary, Eastern Cape, South Africa. Afr. J. Aquat. Sci. 33 83-86. http://dx.doi.org/10.2989/AJAS.2007.33.1.10.394

WALKER DR, PERISSONOTTO R and BALLY RPA (2001) Phytoplankton/protozoan dynamics in the Nyara Estuary, a small temporarily open system in the Eastern Cape (South Africa). Afr. J. Aquat. Sci. 26 31-38. http://dx.doi.org/10.2989/16085910109503721

WHITFIELD AK (1992) Juvenile fish recruitment over an estuarine sand bar. Ichthos 3623 .

WHITFIELD AK (1998) Biology and ecology of fishes in Southern African estuaries. Icthyol. Monogr. JLB Smith Inst. Ichthyol. 2 $1-223$.

WHITFIELD AK and BLABER SJM (1979) The distribution of the freshwater cichlid Sarotherodon mossambicus in estuarine systems. Environ. Biol. Fishes 4 77-81. http://dx.doi.org/10.1007/ BF00005931

WHITFIELD AK and COWLEY PD (2010) The status of fish conservation in South African estuaries. J. Fish Biol. 76 2067-2089. http:// dx.doi.org/10.1111/j.1095-8649.2010.02641.x

WHITFIELD AK and KOK HM (1992) Recruitment of juvenile marine fishes into permanently open and seasonally open estuarine systems on the southeast coast of South Africa. Ichthyol. Bull. JLB Smith Inst. Ichthyol. 57 1-39. 
APPENDIX 1

\begin{tabular}{|c|c|c|c|c|c|c|c|c|c|c|c|c|}
\hline \multicolumn{13}{|c|}{ 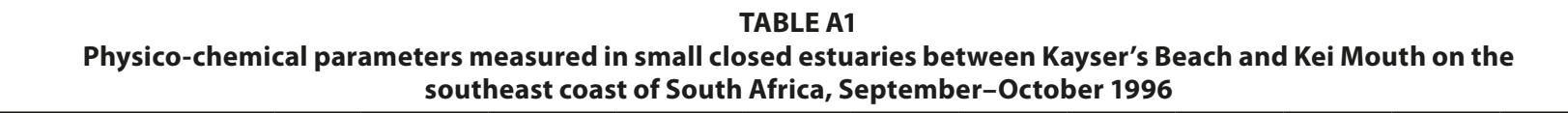 } \\
\hline \multirow[t]{2}{*}{ System } & \multirow[t]{2}{*}{ Site } & \multirow[t]{2}{*}{$\begin{array}{l}\text { Depth } \\
\text { (m) }\end{array}$} & \multicolumn{2}{|c|}{$\begin{array}{c}\text { Temperature } \\
\left({ }^{\circ} \mathrm{C}\right)\end{array}$} & \multicolumn{2}{|c|}{ Salinity } & \multicolumn{2}{|c|}{$\begin{array}{l}\text { Dissolved } \\
\text { oxygen } \\
\left(\mathbf{m g} \cdot \mathrm{L}^{-1}\right)\end{array}$} & \multicolumn{2}{|c|}{$\begin{array}{c}\text { Turbidity } \\
\text { (NTU) }\end{array}$} & \multicolumn{2}{|c|}{ pH } \\
\hline & & & $\mathbf{S}$ & B & $\mathbf{S}$ & B & $\mathbf{S}$ & B & $\mathbf{S}$ & B & $\mathbf{S}$ & B \\
\hline \multirow{3}{*}{ Shelbertsstroom } & 1 & 0.2 & 20.1 & & 7.0 & & 11.7 & & 4.0 & & 8.1 & \\
\hline & 2 & 2.1 & 19.9 & 19.3 & 6.8 & 6.8 & 12.3 & 11.4 & 5.0 & 9.0 & 8.1 & 8.0 \\
\hline & 3 & 0.6 & 19.7 & 19.8 & 6.8 & 6.8 & 11.8 & 11.7 & 6.0 & 9.0 & 8.1 & 8.1 \\
\hline \multirow{3}{*}{ Lilyvale } & 1 & 0.2 & 22.1 & & 17.9 & & 9.4 & & 15.0 & & 8.0 & \\
\hline & 2 & 1.3 & 20.8 & 20.0 & 17.6 & 17.6 & 10.0 & 9.1 & 22.0 & 26.0 & 8.0 & 8.0 \\
\hline & 3 & 0.9 & 21.9 & 20.1 & 17.5 & 17.3 & 9.9 & 8.7 & 11.0 & 34.0 & 8.0 & 7.9 \\
\hline \multirow{3}{*}{ Ross' Creek } & 1 & 1.0 & 18.5 & 18.5 & 6.7 & 6.8 & 7.9 & 7.9 & 20.0 & 20.0 & 8.0 & 8.0 \\
\hline & 2 & 0.2 & 19.3 & & 6.3 & & 6.3 & & 20.0 & & 7.8 & \\
\hline & 3 & 0.5 & 19.2 & 19.2 & 6.5 & 6.6 & 5.6 & 5.4 & 20.0 & 20.0 & 7.6 & 7.6 \\
\hline \multirow{3}{*}{ Mlele } & 1 & 0.9 & 19.7 & 19.9 & 15.3 & 15.4 & 7.8 & 7.8 & 16.0 & 16.0 & 7.9 & 7.9 \\
\hline & 2 & 1.2 & 19.7 & 19.9 & 15.3 & 15.4 & 7.4 & 7.4 & 16.0 & 16.0 & 7.8 & 7.8 \\
\hline & 3 & 1.1 & 19.7 & 19.7 & 15.1 & 15.3 & 7.4 & 7.3 & 16.0 & 16.0 & 7.8 & 7.8 \\
\hline \multirow{3}{*}{ Mcantsi } & 1 & 1.1 & 22.9 & 22.9 & 14.5 & 14.5 & 8.2 & 8.4 & 8.0 & 5.0 & 8.1 & 8.1 \\
\hline & 2 & 1.0 & 23.1 & 22.7 & 12.9 & 14.0 & 6.3 & 5.2 & 3.0 & 4.0 & 7.8 & 7.7 \\
\hline & 3 & 1.0 & 23.8 & 22.8 & 13.8 & 14.9 & 6.4 & 7.4 & 9.0 & 13.0 & 7.8 & 7.7 \\
\hline \multirow{2}{*}{ Hlozi } & 1 & 0.9 & 19.9 & 20.0 & 27.6 & 27.6 & 7.5 & 7.2 & 2.0 & 2.0 & 7.7 & 7.7 \\
\hline & 2 & 1.7 & 20.3 & 20.4 & 27.7 & 27.7 & 7.3 & 7.1 & 5.0 & 5.0 & 7.7 & 7.7 \\
\hline \multirow{3}{*}{ Hickmans } & 1 & 1.5 & 21.9 & 22.0 & 17.7 & 18.2 & 7.8 & 6.8 & 4.0 & 5.0 & 7.7 & 7.6 \\
\hline & 2 & 2.0 & 21.5 & 22.0 & 16.6 & 21.0 & 8.8 & 4.0 & 4.0 & 11.0 & 7.8 & 7.3 \\
\hline & 3 & 1.3 & 22.5 & 22.0 & 18.0 & 21.5 & 6.8 & 4.4 & 3.0 & 4.0 & 7.5 & 7.2 \\
\hline Blind & 1 & 0.2 & 17.8 & & 0.8 & & 8.9 & & 19.0 & & 7.9 & \\
\hline \multirow{2}{*}{ Hlaze } & 1 & 0.3 & 21.7 & & 23.6 & & 9.1 & & 3.0 & & 8.0 & \\
\hline & 2 & 0.6 & 21.3 & & 22.4 & & 9.6 & & 4.0 & & 8.1 & \\
\hline \multirow{2}{*}{ Cunge } & 1 & 1.4 & 25.4 & 25.8 & 17.6 & 20.0 & 7.5 & 6.5 & 3.0 & 3.0 & 7.8 & 7.6 \\
\hline & 2 & 2.8 & 23.3 & 24.0 & 15.7 & 21.0 & 9.1 & 6.4 & 3.0 & 7.0 & 8.0 & 7.3 \\
\hline \multirow{2}{*}{ Haga-Haga } & 1 & 0.2 & 22.3 & & 25.6 & & 8.1 & & 14.0 & & 7.7 & \\
\hline & 2 & 0.5 & 21.3 & 20.4 & 25.2 & 26.6 & 8.0 & 8.0 & 32.0 & 55.0 & 7.7 & 7.7 \\
\hline Mtendwe & 1 & 0.8 & 21.9 & 21.6 & 0.3 & 0.3 & 3.0 & 3.7 & 35.0 & 32.0 & 7.9 & 7.8 \\
\hline \multirow{3}{*}{ Cwili } & 1 & 0.3 & 21.6 & & 11.3 & & 7.6 & & 31.0 & & 7.7 & \\
\hline & 2 & 0.9 & 21.8 & 19.0 & 10.5 & 24.6 & 7.1 & 7.9 & 30.0 & 30.0 & 7.7 & 7.9 \\
\hline & 3 & 1.2 & 21.6 & 18.8 & 11.0 & 25.5 & 7.5 & 8.3 & 40.0 & 50.0 & 7.7 & 7.9 \\
\hline
\end{tabular}




\begin{tabular}{|c|c|c|c|c|c|c|c|c|c|c|c|c|}
\hline \multicolumn{13}{|c|}{ 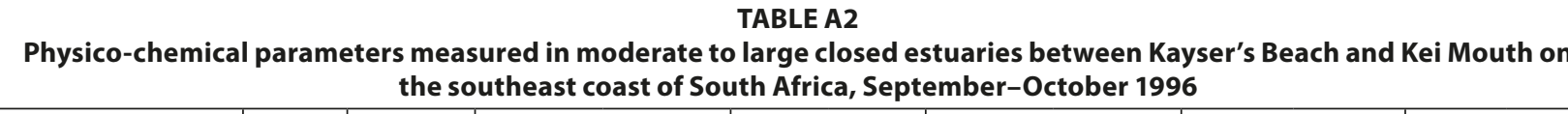 } \\
\hline \multirow[t]{2}{*}{ System } & \multirow[t]{2}{*}{ Site } & \multirow{2}{*}{$\begin{array}{l}\text { Depth } \\
\text { (m) }\end{array}$} & \multicolumn{2}{|c|}{$\begin{array}{c}\text { Temperature } \\
\left({ }^{\circ} \mathrm{C}\right)\end{array}$} & \multicolumn{2}{|c|}{ Salinity } & \multicolumn{2}{|c|}{$\begin{array}{c}\text { Dissolved oxygen } \\
\left(\mathrm{mg} \cdot \mathrm{L}^{-1}\right)\end{array}$} & \multicolumn{2}{|c|}{$\begin{array}{c}\text { Turbidity } \\
\text { (NTU) }\end{array}$} & \multicolumn{2}{|c|}{$\mathbf{p H}$} \\
\hline & & & $\mathbf{S}$ & B & $\mathbf{S}$ & B & $\mathbf{S}$ & B & $\mathbf{S}$ & B & $\mathbf{S}$ & B \\
\hline \multirow{5}{*}{ Ncera } & 1 & 1.2 & 19.8 & 19.8 & 34.3 & 34.3 & 10.0 & 12.2 & 0.0 & 0.0 & 8.4 & 8.6 \\
\hline & 2 & 0.9 & 20.5 & 20.3 & 34.2 & 34.3 & 8.1 & 8.0 & 4.0 & 4.0 & 8.1 & 8.1 \\
\hline & 3 & 1.2 & 20.6 & 20.6 & 34.0 & 34.0 & 6.4 & 6.4 & 6.0 & 6.0 & 7.8 & 7.8 \\
\hline & 4 & 1.0 & 20.9 & 21.0 & 33.3 & 33.4 & 5.7 & 5.6 & 2.0 & 2.0 & 7.6 & 7.6 \\
\hline & 5 & 1.8 & 20.5 & 20.6 & 32.3 & 32.5 & 7.4 & 7.3 & 0.0 & 0.0 & 7.7 & 7.8 \\
\hline \multirow{6}{*}{ Gxulu } & 1 & 1.1 & 20.9 & 21.0 & 30.0 & 30.0 & 7.3 & 6.6 & 3.0 & 2.0 & 7.8 & 7.8 \\
\hline & 2 & 1.5 & 23.1 & 21.8 & 29.0 & 30.1 & 7.6 & 6.1 & 5.0 & 6.0 & 7.8 & 7.8 \\
\hline & 3 & 1.5 & 20.9 & 21.0 & 30.3 & 30.3 & 6.5 & 6.4 & 7.0 & 7.0 & 7.8 & 7.8 \\
\hline & 4 & 1.1 & 21.9 & 21.6 & 29.5 & 30.2 & 6.7 & 7.1 & 3.0 & 3.0 & 7.8 & 7.8 \\
\hline & 5 & 1.6 & 23.4 & 22.5 & 29.0 & 30.0 & 6.4 & 5.3 & 0.0 & 4.0 & 7.8 & 7.7 \\
\hline & 6 & 1.4 & 23.1 & 23.5 & 28.0 & 29.3 & 5.6 & 5.5 & 1.0 & 6.0 & 7.7 & 7.7 \\
\hline \multirow{3}{*}{ Goda } & 1 & 2.4 & 20.4 & 20.6 & 32.5 & 32.6 & 6.5 & 6.4 & 3.0 & 3.0 & 7.8 & 7.8 \\
\hline & 2 & 1.9 & 20.9 & 21.0 & 32.5 & 32.6 & 6.4 & 5.5 & 10.0 & 15.0 & 7.8 & 7.8 \\
\hline & 3 & 1.6 & 21.5 & 21.6 & 32.4 & 32.7 & 6.3 & 5.3 & 3.0 & 3.0 & 7.9 & 7.9 \\
\hline \multirow{4}{*}{ Qinira } & 1 & 1.7 & 21.3 & 21.5 & 28.5 & 28.6 & 6.9 & 6.0 & 3.0 & 3.0 & 7.8 & 7.8 \\
\hline & 2 & 1.6 & 21.1 & 21.3 & 28.2 & 28.3 & 6.9 & 6.9 & 7.0 & 7.0 & 7.8 & 7.8 \\
\hline & 3 & 1.5 & 21.1 & 21.5 & 27.2 & 28.2 & 7.1 & 5.8 & 5.0 & 8.0 & 7.7 & 7.6 \\
\hline & 4 & 2.0 & 22.0 & 22.2 & 27.1 & 28.0 & 6.5 & 5.1 & 3.0 & 2.0 & 7.6 & 7.5 \\
\hline \multirow{4}{*}{ Bulura } & 1 & 0.9 & 21.7 & 21.7 & 30.7 & 30.8 & 7.9 & 7.8 & 3.0 & 3.0 & 7.9 & 7.9 \\
\hline & 2 & 1.4 & 22.3 & 22.5 & 28.7 & 30.1 & 7.7 & 7.3 & 3.0 & 8.0 & 8.0 & 7.9 \\
\hline & 3 & 0.9 & 22.9 & 23.1 & 29.2 & 29.4 & 7.9 & 8.0 & 2.0 & 3.0 & 8.1 & 8.1 \\
\hline & 4 & 1.5 & 23.7 & 25.3 & 25.5 & 29.5 & 7.4 & 6.4 & 2.0 & 8.0 & 7.8 & 7.8 \\
\hline \multirow{4}{*}{ Cintsa } & 1 & 1.6 & 22.3 & 22.3 & 31.8 & 31.8 & 6.5 & 6.5 & 3.0 & 3.0 & 7.6 & 7.6 \\
\hline & 2 & 1.6 & 23.3 & 23.5 & 31.7 & 31.8 & 5.5 & 5.3 & 5.0 & 4.0 & 7.5 & 7.5 \\
\hline & 3 & 1.2 & 24.3 & 24.2 & 31.1 & 31.1 & 5.0 & 5.0 & 3.0 & 3.0 & 7.5 & 7.5 \\
\hline & 4 & 1.1 & 25.1 & 25.2 & 29.7 & 30.0 & 5.2 & 5.2 & 3.0 & 3.0 & 7.4 & 7.4 \\
\hline \multirow{4}{*}{ Cefane } & 1 & 0.9 & 22.3 & 22.3 & 29.2 & 29.2 & 5.2 & 5.1 & 3.0 & 4.0 & 7.8 & 7.8 \\
\hline & 2 & 0.9 & 23.4 & 23.4 & 29.2 & 29.2 & 5.3 & 5.2 & 11.0 & 11.0 & 7.8 & 7.8 \\
\hline & 3 & 1.4 & 24.6 & 24.8 & 29.0 & 29.1 & 4.9 & 4.8 & 8.0 & 15.0 & 7.6 & 7.6 \\
\hline & 4 & 0.5 & 23.5 & 23.7 & 28.0 & 28.3 & 4.8 & 4.7 & 2.0 & 3.0 & 7.3 & 7.3 \\
\hline \multirow{3}{*}{ Kwenxura } & 1 & 0.2 & 24.1 & & 16.7 & & 6.2 & & 33.0 & & 7.8 & \\
\hline & 2 & 0.7 & 19.0 & 18.9 & 32.0 & 32.1 & 6.7 & 6.2 & 69.0 & 58.0 & 7.9 & 7.9 \\
\hline & 3 & 1.5 & 18.2 & 18.3 & 32.3 & 32.4 & 7.8 & 8.0 & 5.0 & 8.0 & 8.0 & 8.0 \\
\hline \multirow{2}{*}{ Nyara } & 1 & 0.8 & 18.5 & 18.0 & 27.0 & 31.3 & 3.5 & 3.7 & 50.0 & 31.0 & 7.9 & 8.0 \\
\hline & 2 & 0.3 & 20.6 & & 7.0 & & 3.3 & & 139.0 & & 7.9 & \\
\hline \multirow{3}{*}{ Morgan } & 1 & 0.5 & 22.2 & 19.9 & 24.7 & 26.2 & 7.8 & 8.1 & 88.0 & 103.0 & 7.9 & 7.9 \\
\hline & 2 & 0.5 & 22.3 & 21.8 & 0.3 & 0.4 & 8.8 & 8.8 & 110.0 & 110.0 & 7.5 & 7.4 \\
\hline & 3 & 0.7 & 22.9 & 22.8 & 0.1 & 0.1 & 8.4 & 8.4 & 103.0 & 108.0 & 7.3 & 7.3 \\
\hline
\end{tabular}


TABLE A3

Physico-chemical parameters measured in predominantly open estuaries between Kayser's Beach and Kei Mouth on the southeast coast of South Africa, September-October 1996

\begin{tabular}{|c|c|c|c|c|c|c|c|c|c|c|c|c|}
\hline \multirow[t]{2}{*}{ System } & \multirow[t]{2}{*}{ Site } & \multirow{2}{*}{$\begin{array}{l}\text { Depth } \\
\text { (m) }\end{array}$} & \multicolumn{2}{|c|}{$\begin{array}{c}\text { Temperature } \\
\left({ }^{\circ} \mathrm{C}\right)\end{array}$} & \multicolumn{2}{|c|}{ Salinity } & \multicolumn{2}{|c|}{$\begin{array}{l}\text { Dissolved oxygen } \\
\left(\mathrm{mg}^{\mathrm{L}} \mathrm{L}^{-1}\right)\end{array}$} & \multicolumn{2}{|c|}{$\begin{array}{l}\text { Turbidity } \\
\text { (NTU) }\end{array}$} & \multicolumn{2}{|c|}{ pH } \\
\hline & & & $\mathbf{S}$ & B & $\mathbf{S}$ & B & $\mathbf{S}$ & B & $\mathbf{S}$ & B & $\mathbf{S}$ & B \\
\hline \multirow{3}{*}{ Buffalo } & 1 & 5.3 & 18.1 & 17.2 & 31.9 & 32.2 & 6.8 & 7.2 & 10.0 & 15.0 & 7.9 & 7.9 \\
\hline & 2 & 3.6 & 18.6 & 15.9 & 31.5 & 32.8 & 6.8 & 7.0 & 7.0 & 19.0 & 7.9 & 7.9 \\
\hline & 3 & 1.4 & 19.8 & 19.4 & 28.6 & 30.0 & 9.8 & 9.4 & 13.0 & 13.0 & 7.9 & 7.9 \\
\hline \multirow{5}{*}{ Nahoon } & 1 & 2.0 & 19.8 & 19.8 & 33.3 & 33.4 & 7.0 & 6.9 & 1.0 & 1.0 & 8.1 & 8.1 \\
\hline & 2 & 3.7 & 18.4 & 18.4 & 32.8 & 33.0 & 7.4 & 7.3 & 9.0 & 9.0 & 8.0 & 8.0 \\
\hline & 3 & 3.8 & 18.8 & 18.7 & 32.8 & 32.9 & 10.0 & 9.2 & 7.0 & 7.0 & 8.0 & 8.0 \\
\hline & 4 & 1.2 & 19.3 & 19.2 & 32.2 & 32.6 & 9.9 & 9.3 & 5.0 & 5.0 & 7.8 & 7.9 \\
\hline & 5 & 0.9 & 21.2 & 20.5 & 31.3 & 31.8 & 8.9 & 8.7 & 7.0 & 8.0 & 7.8 & 7.7 \\
\hline \multirow{4}{*}{ Gqunube } & 1 & 1.2 & 18.6 & 18.5 & 32.8 & 32.9 & 7.7 & 7.6 & 33.0 & 25.0 & 8.0 & 8.0 \\
\hline & 2 & 2.2 & 19.7 & 19.6 & 32.7 & 32.8 & 6.9 & 6.9 & 11.0 & 19.0 & 7.9 & 8.0 \\
\hline & 3 & 2.2 & 20.6 & 20.5 & 32.6 & 32.9 & 6.7 & 6.4 & 12.0 & 25.0 & 7.9 & 7.9 \\
\hline & 4 & 1.1 & 21.1 & 21.2 & 32.9 & 32.9 & 6.1 & 6.1 & 7.0 & 7.0 & 7.8 & 7.8 \\
\hline \multirow{5}{*}{ Kwelera } & 1 & 1.4 & 18.7 & 18.2 & 32.6 & 32.7 & 7.3 & 7.3 & 13.0 & 13.0 & 7.8 & 7.9 \\
\hline & 2 & 1.4 & 20.4 & 20.0 & 32.3 & 32.5 & 7.1 & 7.2 & 20.0 & 30.0 & 7.8 & 7.8 \\
\hline & 3 & 0.5 & 22.6 & 22.6 & 32.1 & 32.1 & 7.2 & 7.2 & 26.0 & 29.0 & 7.8 & 7.8 \\
\hline & 4 & 2.3 & 23.0 & 20.6 & 31.7 & 32.3 & 6.6 & 6.4 & 8.0 & 25.0 & 7.6 & 7.6 \\
\hline & 5 & 2.2 & 22.5 & 21.5 & 31.0 & 31.9 & 6.5 & 5.6 & 12.0 & 12.0 & 7.6 & 7.5 \\
\hline \multirow{4}{*}{ Quko } & 1 & 1.3 & 19.6 & 17.8 & 19.3 & 31.5 & 8.1 & 8.4 & 130.0 & 27.0 & 7.9 & 8.0 \\
\hline & 2 & 1.2 & 21.8 & 20.0 & 0.1 & 17.4 & 8.0 & 9.5 & 240.0 & 103.0 & 7.5 & 7.9 \\
\hline & 3 & 1.4 & 21.9 & 20.9 & 0.1 & 14.4 & 7.8 & 8.3 & 515.0 & 496.0 & 7.7 & 7.8 \\
\hline & 4 & 2.1 & 21.6 & 21.6 & 0.0 & 0.0 & 8.0 & 8.5 & 301.0 & 308.0 & 7.6 & 7.6 \\
\hline
\end{tabular}




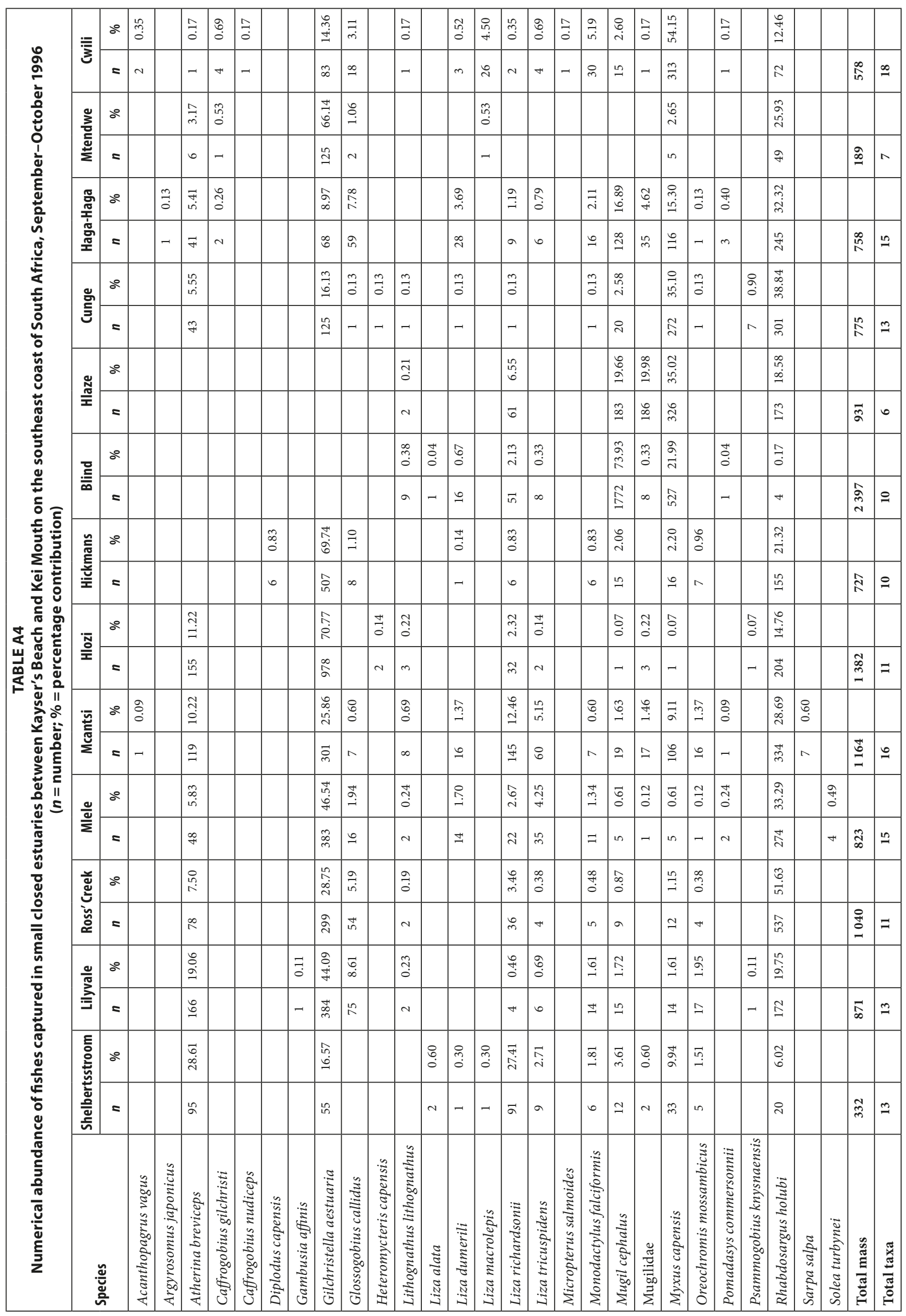




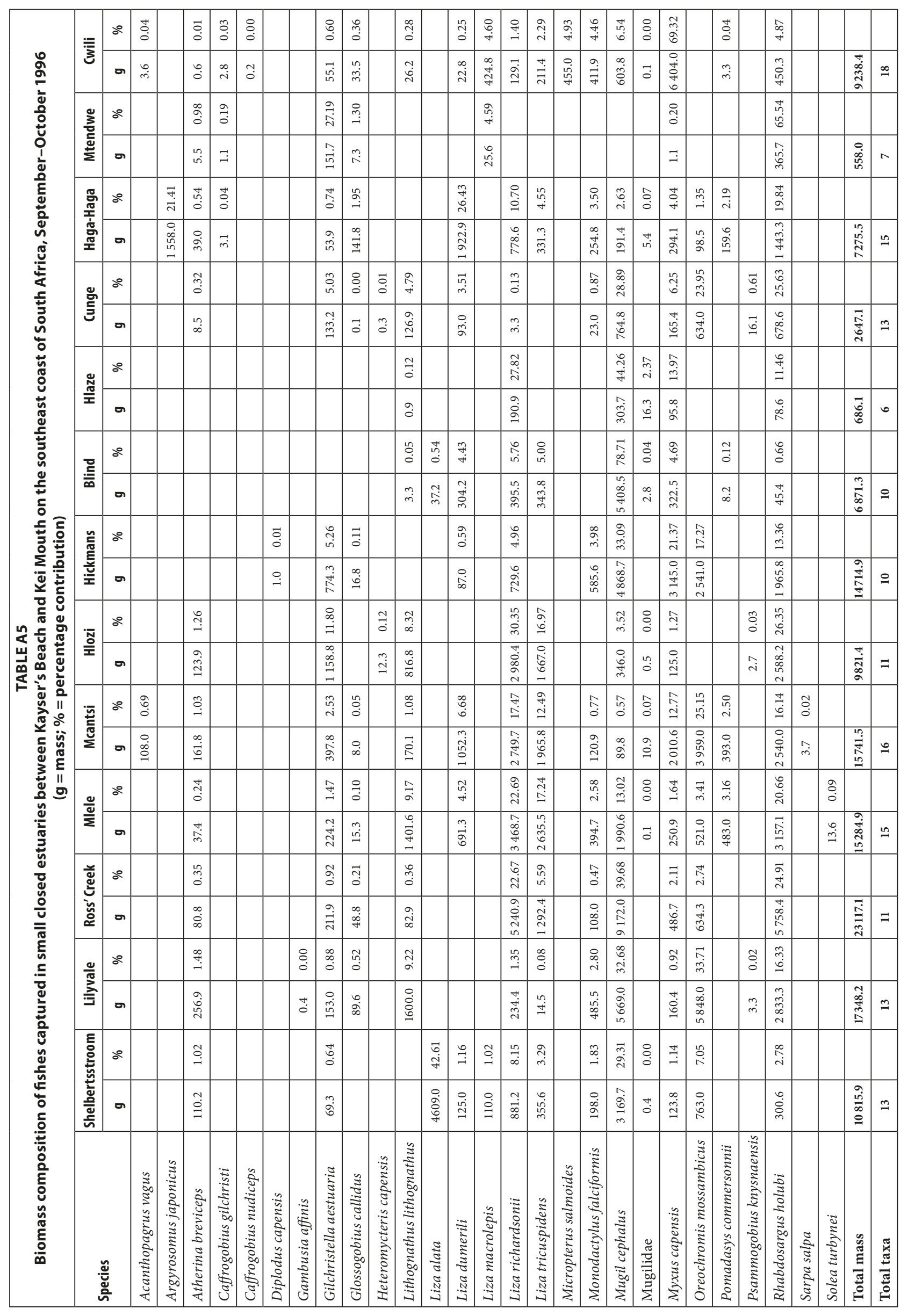




\begin{tabular}{|c|c|c|c|c|c|c|c|c|c|c|c|c|c|c|c|c|c|c|c|c|c|c|c|c|c|c|c|c|c|c|c|c|}
\hline \multirow{12}{*}{\multicolumn{2}{|c|}{ 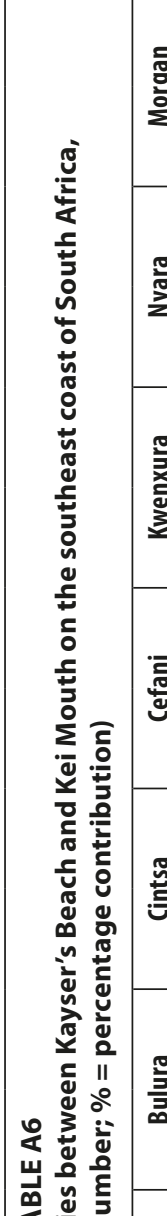 }} & $\therefore$ & & & $\begin{array}{l}a \\
\dot{0} \\
\dot{0}\end{array}$ & & $\mid \begin{array}{l}\stackrel{\leftrightarrow}{O} \\
O\end{array}$ & & & & $\mid \begin{array}{c}\infty \\
\substack{0 \\
0 \\
0}\end{array}$ & 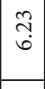 & & & $\begin{array}{l}a \\
\dot{0}\end{array}$ & $\begin{array}{l}\underset{1}{\infty} \\
\infty\end{array}$ & $\vec{\Im}$ & $\begin{array}{l}\text { वे } \\
\text { r. }\end{array}$ & & $\begin{array}{ll}0 \\
\dot{0}\end{array}$ & 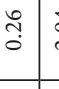 & 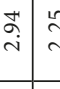 & 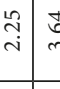 & 苛 & $\begin{array}{l}\vec{n} \\
\vec{i}\end{array}$ & & $\begin{array}{l}\stackrel{8}{:} \\
i\end{array}$ & & ְ̊ & & $\begin{array}{c}\infty \\
\stackrel{\infty}{\infty} \\
i n\end{array}$ & \\
\hline & & $=$ & & & -1 & & $=$ & & & & 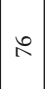 & $N$ & & & -7 & ณ & $\exists$ & $\hat{m}$ & & -7 & $m$ & $\dot{m}$ & $\stackrel{i}{i}$ & $\mp \mid-$ & ì & & $\stackrel{m}{m}$ & & $a$ & & $\widetilde{్}$ & \\
\hline & & $\AA^{\circ}$ & & & & $\stackrel{\leftrightarrow}{\circ}$ & $\mid \begin{array}{l}0 \\
0 \\
0\end{array}$ & & & & \begin{tabular}{|l|}
$\infty$ \\
वे. \\
â. \\
\end{tabular} & $\begin{array}{l}\beta \\
\dot{\rho}\end{array}$ & & & & $\tilde{\omega}$ & $\stackrel{?}{\leftrightarrows}$ & $\begin{array}{l}\stackrel{9}{9} \\
\stackrel{0}{-} \\
\end{array}$ & 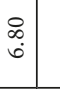 & & $\begin{array}{l}\infty \\
\stackrel{0}{\circ}\end{array}$ & Бे & & $\begin{array}{l}0 \\
8 \\
0 \\
0\end{array}$ & 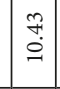 & & & & กิ & & : & \\
\hline & & $=$ & & & & $=$ & $\infty$ & & & & 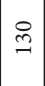 & $\because$ & & & & f & in & $\vec{R}$ & $\dot{m}$ & & m & + & & i & 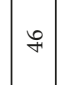 & & & & - & & $f$ & \\
\hline & & $\therefore$ & $\mid \begin{array}{l}0 \\
0 \\
0 \\
0\end{array}$ & & 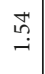 & 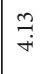 & & $\mid \begin{array}{l}0 \\
\dot{0} \\
0\end{array}$ & $\begin{array}{l}0 \\
\dot{0} \\
0\end{array}$ & 定 & 敨 & $\stackrel{\infty}{\rightarrow}$ & & oे & & $\begin{array}{l}\infty \\
\stackrel{\sim}{i}\end{array}$ & $\stackrel{+}{0}$ & $\begin{array}{l}\infty \\
\stackrel{\sim}{0} \\
\stackrel{i}{\mid}\end{array}$ & î̀ & & 苦 & : & $\begin{array}{lll}0 \\
0 \\
0\end{array}$ & 年 & $\stackrel{\pi}{0}$ & & F. & & & & 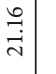 & \\
\hline & & $=$ & -7 & & $\stackrel{m}{m}$ & $\vec{\sigma}$ & & $\sim$ & $\sim$ & $\sim$ & 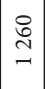 & o & & $\sim$ & & in & $m$ & in & in & & $\simeq$ & $\therefore=$ & $\Rightarrow$ & $\therefore$ & $m$ & & $\sigma$ & & & & 荣 & \\
\hline & & $\therefore$ & & & $\begin{array}{l}\vec{n} \\
0 \\
0\end{array}$ & \begin{tabular}{|c}
0 \\
0 \\
0 \\
j.
\end{tabular} & $\begin{array}{c}\overrightarrow{3} \\
0 \\
0\end{array}$ & $\stackrel{7}{0}$ & & & $\mid \begin{array}{l}\vec{J} \\
\text { d. }\end{array}$ & $\mid \begin{array}{l}\infty \\
\stackrel{\infty}{\mathfrak{d}} \\
\stackrel{]}{2}\end{array}$ & & : & & $\stackrel{\substack{m \\
\dot{m}}}{1}$ & శి & $\left|\begin{array}{c}0 \\
\infty \\
0 \\
0\end{array}\right|$ & 今े & & ?ㅇㅇ & $\overrightarrow{0}$ & & S. & $\mid \begin{array}{c}\overrightarrow{0} \\
0 \\
0\end{array}$ & & $\because$ & 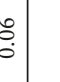 & 足 & & 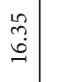 & \\
\hline & & $=$ & & & $\sigma$ & 8 & 0 & $m$ & & & 字 & సิ & & -7 & & $i$ & + & $\stackrel{2}{2}$ & $m$ & & $\therefore$ & $\sim$ & & $\Rightarrow$ & 0 & & $m$ & - & $\because$ & & $\stackrel{\infty}{\sim}$ & \\
\hline & & $\therefore$ & & & $\begin{array}{l}0 \\
\dot{0} \\
0\end{array}$ & 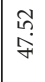 & ô & & & & స్ & $\underset{+}{\vec{f}}$ & & $\stackrel{\circ}{0}$ & $\mid \begin{array}{l}a \\
\dot{0} \\
0\end{array}$ & 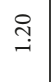 & & $\mid$ & $\stackrel{\infty}{\circ}$ & & $\begin{array}{l}\Delta \\
0 \\
0\end{array}$ & 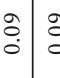 & $\begin{array}{lll}0 \\
:\end{array}$ & c. & $\mid \begin{array}{l}0 \\
0 \\
0\end{array}$ & & $\begin{array}{l}\dot{a} \\
\dot{0}\end{array}$ & d. & $\int_{0}^{+}$ & & 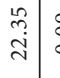 & $\stackrel{8}{\circ}$ \\
\hline & & $=$ & & & - & 点 & -7 & & & & $\stackrel{\infty}{=}$ & in & & $\sim$ & -1 & \pm & & $\infty$ & $\infty$ & & $=$ & $-1-7$ & $-\pi \overline{i n}$ & in & $m$ & & - & + & H & & & - \\
\hline & & $\therefore$ & & & & $\begin{array}{l}\infty \\
\stackrel{\sim}{\sim}\end{array}$ & $\begin{array}{l}0 \\
0 \\
0 \\
0\end{array}$ & $\overline{0}$ & & & 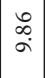 & $\stackrel{\infty}{\Im}$ & $F_{0}$ & 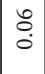 & $\mid \begin{array}{l}0 \\
\\
0\end{array}$ & 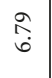 & 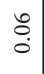 & $\mid$ & $\stackrel{\infty}{\infty} \underset{0}{0}$ & & ब⿳亠丷厂ٍ & \begin{tabular}{c|ccc}
$\substack{0 \\
\hdashline}$ & \multicolumn{2}{c}{}
\end{tabular} & \begin{tabular}{c|c}
$\infty$ \\
\hdashline \\
\hdashline
\end{tabular} & \begin{tabular}{l}
2 \\
\hdashline \\
$\check{r}$
\end{tabular} & $\overrightarrow{0}$ & & $\stackrel{?}{0}$ & & $\overrightarrow{0}_{0}$ & & $\begin{array}{l}\text { â } \\
\stackrel{8}{i n}\end{array}$ & \\
\hline & & $=$ & & & & J్ & $\infty$ & $\sim$ & & & 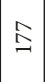 & $\approx$ & $\sim$ & -7 & -7 & $\mathbb{I}$ & -7 & $\stackrel{\infty}{\rightarrow}$ & $\simeq$ & & $n$ & in 7 & \pm 1 & R & $\sim$ & & $\infty$ & & $=$ & & $\stackrel{n}{a}$ & \\
\hline 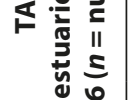 & $\stackrel{\Xi}{\cong}$ & $\therefore$ & & $\mid \begin{array}{l}* \\
0 \\
0\end{array}$ & & | & & : & & & $\begin{array}{l}\text { hn } \\
\text { ô } \\
\text { in }\end{array}$ & $\stackrel{\overbrace{}}{\rightarrow}$ & & $F_{0}$ & $\begin{array}{l}\text { â } \\
0 \\
0\end{array}$ & $\begin{array}{l}\hat{n} \\
0 \\
0\end{array}$ & $\begin{array}{l}\overrightarrow{0} \\
\dot{0}\end{array}$ & $\mid \begin{array}{c}0 \\
\stackrel{-}{0}\end{array}$ & ô. & & $\stackrel{+}{0}$ & & ָֻ & $\begin{array}{c}\hat{E} \\
\text { s. }\end{array}$ & $\mid \begin{array}{l}0 \\
0 \\
0 \\
0\end{array}$ & & & $\stackrel{t}{0}$ & $\infty_{0}^{\infty}$ & & 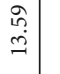 & \\
\hline 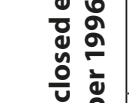 & $\bar{z}$ & $=$ & & -7 & & $\mid \begin{array}{l}\infty \\
\infty \\
i n\end{array}$ & & $\sim$ & & & $\mid \begin{array}{l}\overrightarrow{2} \\
2\end{array}$ & $\infty$ & & $m$ & $n$ & $\cong$ & -7 & 文 & $\sim$ & & + & & $\sigma \mid 2$ & त & $\cong$ & & & - & 4 in & & $\stackrel{\infty}{\infty}$ & \\
\hline 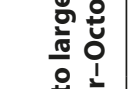 & 용 & $\therefore$ & & & 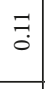 & 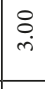 & & $\mid \begin{array}{c}H \\
\dot{0}\end{array}$ & & $\because$ & \begin{tabular}{|l}
7 \\
\multirow{0}{*}{} \\
0
\end{tabular} & $\stackrel{\leftrightarrow}{\stackrel{\leftrightarrow}{\leftrightarrow}}$ & : & $\begin{array}{l}0 \\
0\end{array}$ & $\mid \begin{array}{l} \pm \\
0 \\
0\end{array}$ & $\stackrel{5 n}{\mathrm{~s}}$ & & $\begin{array}{l}\hat{\sigma} \\
\hat{0}\end{array}$ & 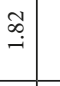 & & $\stackrel{\circ}{\circ}:$ & $\begin{array}{c}* \\
\dot{0} \\
\dot{0}\end{array}$ & $\begin{array}{lll}0 \\
\dot{0} \\
\dot{0}\end{array}$ & : & & & $\begin{array}{l}0 \\
\stackrel{0}{\circ}\end{array}$ & $\stackrel{8}{0}$ & ${ }_{0}^{\circ}$ & $\begin{array}{l}\vec{a} \\
0\end{array}$ & $\overrightarrow{\vec{\sigma}}$ & \\
\hline 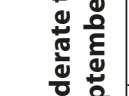 & $\checkmark$ & $=$ & & & $\infty$ & $\tilde{\sim}$ & & $\vec{m}$ & & $n$ & $\mid \begin{array}{l}0 \\
0 \\
0 \\
\vdots \\
+1\end{array}$ & it & $\sim$ & -7 & $m$ & 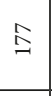 & & 亲 & సे & & $r$ & $m=n$ & $\therefore)$ & $\widehat{\infty}$ & & & + & $\mathrm{N}$ & $1-$ & -7 & $\stackrel{\infty}{\neq}$ & \\
\hline 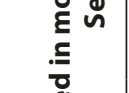 & 를 & $\therefore$ & & & $\stackrel{?}{0}$ & \begin{tabular}{|l}
0 \\
0 \\
0 \\
6
\end{tabular} & & ণิ & & $\stackrel{9}{\circ}$ & \begin{tabular}{|l}
0 \\
$\hat{\overbrace{}}$ \\
bे
\end{tabular} & İ & İ & & वิ & 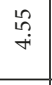 & & $\begin{array}{l}\text { 市 } \\
0 \\
0\end{array}$ & مْ & & 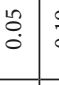 & ठे & & $\begin{array}{l}8 \\
6 \\
\end{array}$ & $\begin{array}{ll}2 \\
0 \\
0\end{array}$ & $\begin{array}{l}\stackrel{0}{0} \\
0 \\
0\end{array}$ & 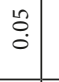 & & $\stackrel{\infty}{\rightarrow}$ & & مू & \\
\hline 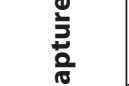 & & $=$ & & & + & \pm & & 6 & & $s$ & 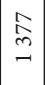 & in & in & & 6 & ప゙ & & 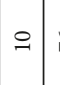 & 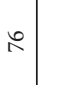 & & $\tau$ & + & & I & $m$ & -1 & - & & के & & $\overrightarrow{\mathrm{\Xi}}$ & \\
\hline 离 & 丞 & $0^{\circ}$ & & & & $\stackrel{2}{\circ}$ & & $\stackrel{\ominus}{\exists}$ & & $\stackrel{2}{0}$ & 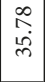 & 总 & & : & $\mid \begin{array}{l}0 \\
0 \\
0\end{array}$ & $\stackrel{F}{+}$ & & $\underset{+}{\stackrel{+}{*}}$ & $\stackrel{\circ}{\rightarrow}$ & & $\stackrel{0}{\circ}$ & કे & 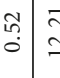 & & & & & & के & & $\begin{array}{ll}\overrightarrow{\hat{i}} & \\
\dot{\hat{i}}\end{array}$ & $\vdots$ \\
\hline 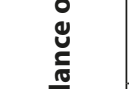 & $z$ & $=$ & & & & $\exists$ & & $\Xi$ & & $s$ & 点 & $\vec{\sim}$ & & -7 & $=$ & 8 & & $\because$ & $\vec{\lambda}$ & & $m$ & $m \mid \infty$ & $\infty \infty_{\infty}^{\infty}$ & & & & & & 0 & & & - \\
\hline 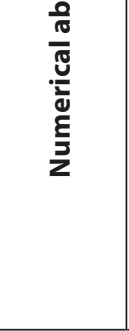 & 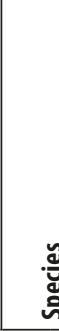 & & 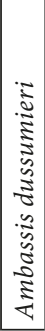 & 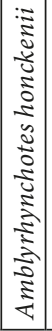 & 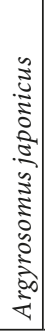 & 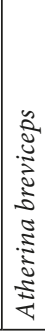 & 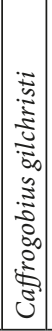 & 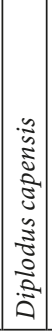 & 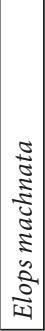 & 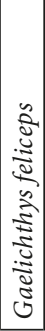 & 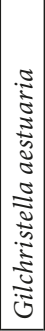 & 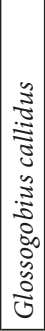 & 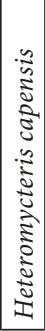 & 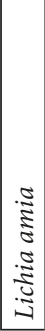 & 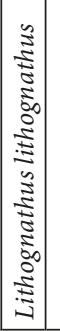 & 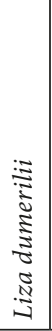 & 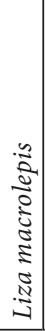 & | & 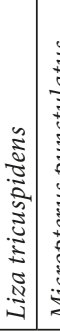 & 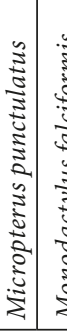 & 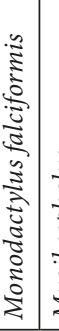 & 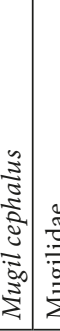 & 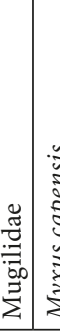 & 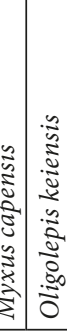 & 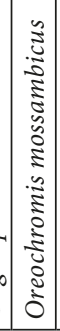 & 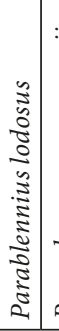 & 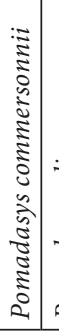 & 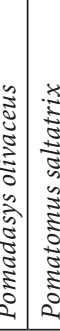 & 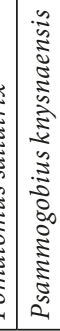 & 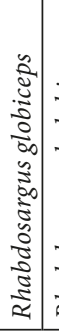 & 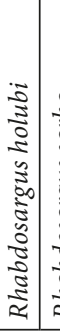 & 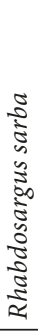 \\
\hline
\end{tabular}




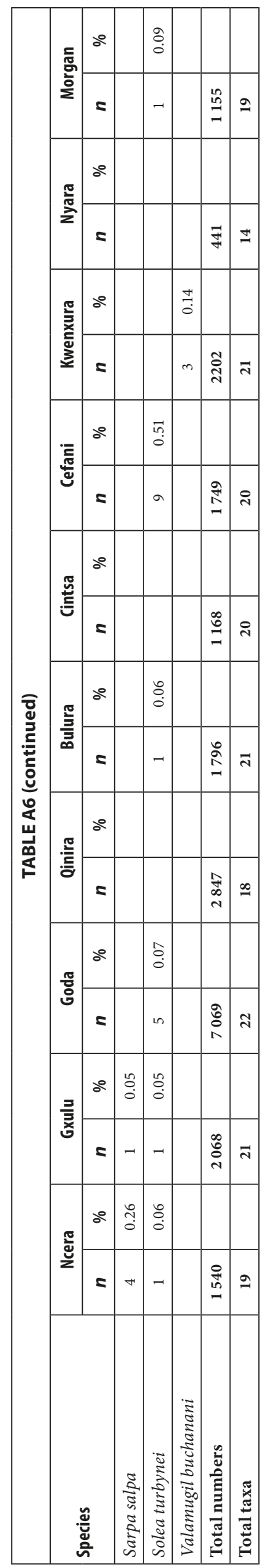

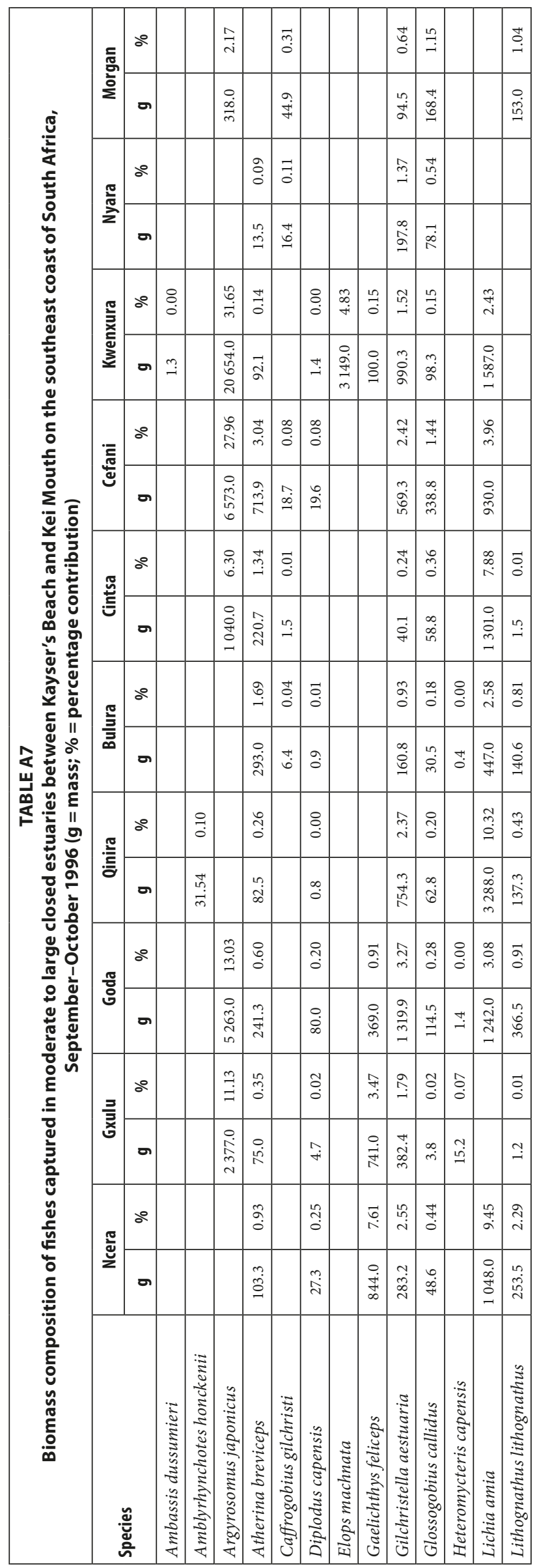




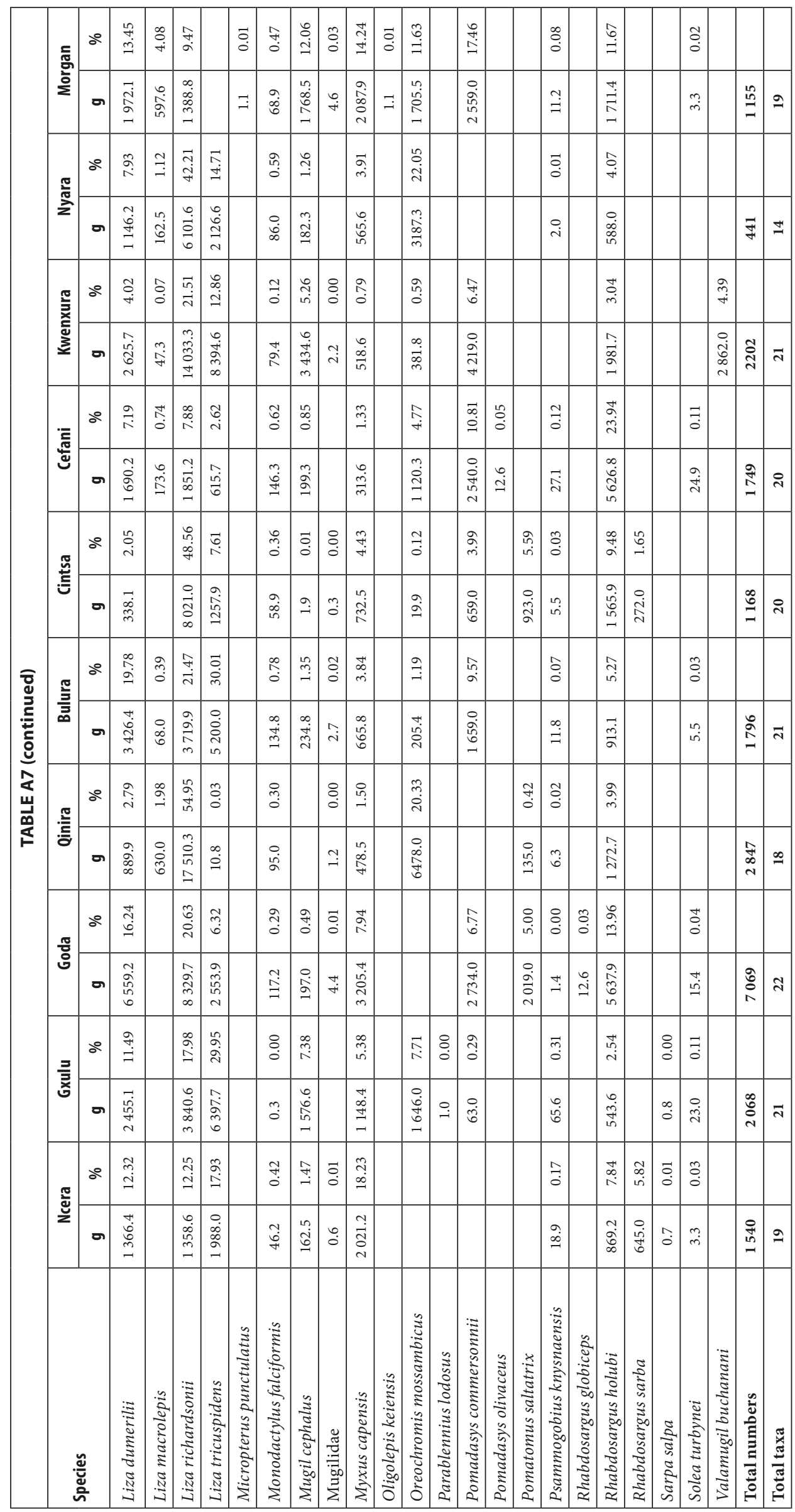


TABLE A8

Numerical abundance of fishes captured in predominantly open estuaries between Kayser's Beach and Kei Mouth on the southeast coast of South Africa, September-October 1996 ( $n=$ number; $\%=$ percentage contribution)

\begin{tabular}{|c|c|c|c|c|c|c|c|c|c|c|}
\hline \multirow{2}{*}{ Species } & \multicolumn{2}{|c|}{ Buffalo } & \multicolumn{2}{|c|}{ Nahoon } & \multicolumn{2}{|c|}{ Gqunube } & \multicolumn{2}{|c|}{ Kwelera } & \multicolumn{2}{|c|}{ Quko } \\
\hline & $n$ & $\%$ & $n$ & $\%$ & $n$ & $\%$ & $n$ & $\%$ & $n$ & $\%$ \\
\hline Acanthopagrus vagus & 2 & 0.51 & & & & & 1 & 0.02 & & \\
\hline Ambassis ambassis & & & & & 2 & 0.04 & & & & \\
\hline Ambassis dussumieri & & & & & 58 & 1.16 & & & & \\
\hline Amblyrhynchotes honckenii & & & & & & & 1 & 0.02 & & \\
\hline Antennarias striatus & & & & & & & 1 & 0.02 & & \\
\hline Argyrosomus japonicus & 3 & 0.76 & 12 & 0.75 & 6 & 0.12 & 11 & 0.24 & 13 & 1.12 \\
\hline Atherina breviceps & 1 & 0.25 & 155 & 9.66 & 200 & 3.99 & 16 & 0.35 & & \\
\hline Caffrogobius gilchristi & 36 & 9.09 & 91 & 5.67 & 74 & 1.48 & 191 & 4.19 & 14 & 1.20 \\
\hline Caffrogobius nudiceps & 8 & 2.02 & 13 & 0.81 & 6 & 0.12 & 7 & 0.15 & & \\
\hline Carcharias taurus & & & 1 & 0.06 & & & & & & \\
\hline Clinus superciliosus & & & 1 & 0.06 & 1 & 0.02 & & & & \\
\hline Dasyatis kuhlii & & & & & & & 1 & 0.02 & & \\
\hline Diplodus capensis & 1 & 0.25 & 21 & 1.31 & 26 & 0.52 & 17 & 0.37 & & \\
\hline Diplodus hottentotus & & & & & 3 & 0.06 & 1 & 0.02 & & \\
\hline Elops machnata & 3 & 0.76 & 16 & 1.00 & 11 & 0.22 & 4 & 0.09 & 4 & 0.34 \\
\hline Gaelichthys feliceps & 3 & 0.76 & & & 3 & 0.06 & 12 & 0.26 & 8 & 0.69 \\
\hline Gilchristella aestuaria & 140 & 35.35 & 435 & 27.10 & 3391 & 67.73 & 2527 & 55.45 & 688 & 59.16 \\
\hline Glossogobius callidus & & & 45 & 2.80 & 228 & 4.55 & 98 & 2.15 & 24 & 2.06 \\
\hline Hemiramphus far & 3 & 0.76 & & & & & & & & \\
\hline Heteromycteris capensis & & & 7 & 0.44 & 9 & 0.18 & 1 & 0.02 & 8 & 0.69 \\
\hline Lichia amia & 1 & 0.25 & & & 6 & 0.12 & 4 & 0.09 & 1 & 0.09 \\
\hline Lithognathus lithognathus & 6 & 1.52 & 4 & 0.25 & 3 & 0.06 & 19 & 0.42 & 2 & 0.17 \\
\hline Liza dumerili & 40 & 10.10 & 118 & 7.35 & 256 & 5.11 & 245 & 5.38 & 29 & 2.49 \\
\hline Liza macrolepis & & & & & 1 & 0.02 & 11 & 0.24 & 2 & 0.17 \\
\hline Liza richardsonii & 3 & 0.76 & 11 & 0.69 & 18 & 0.36 & 320 & 7.02 & 18 & 1.55 \\
\hline Liza tricuspidens & 1 & 0.25 & 14 & 0.87 & 13 & 0.26 & 305 & 6.69 & 4 & 0.34 \\
\hline Monodactylus falciformis & 2 & 0.51 & 1 & 0.06 & 17 & 0.34 & 11 & 0.24 & 4 & 0.34 \\
\hline Mugil cephalus & & & 234 & 14.58 & 89 & 1.78 & 40 & 0.88 & 5 & 0.43 \\
\hline Mugilidae & 24 & 6.06 & 22 & 1.37 & 72 & 1.44 & 109 & 2.39 & 3 & 0.26 \\
\hline Myliobatis aquila & 1 & 0.25 & & & & & & & & \\
\hline Myxus capensis & & & 8 & 0.50 & & & 1 & 0.02 & 17 & 1.46 \\
\hline Platycephalus indicus & 8 & 2.02 & & & & & & & & \\
\hline Pomadasys commersonnii & & & 8 & 0.50 & 9 & 0.18 & 32 & 0.70 & 29 & 2.49 \\
\hline Pomadasys olivaceus & 17 & 4.29 & 25 & 1.56 & 19 & 0.38 & 9 & 0.20 & & \\
\hline Pomatomus saltatrix & 3 & 0.76 & & & 1 & 0.02 & 1 & 0.02 & & \\
\hline Psammogobius knysnaensis & 19 & 4.80 & 12 & 0.75 & 22 & 0.44 & 21 & 0.46 & 11 & 0.95 \\
\hline Raja miraletus & & & & & & & 1 & 0.02 & & \\
\hline Rhabdosargus holubi & 67 & 16.92 & 342 & 21.31 & 436 & 8.71 & 513 & 11.26 & 275 & 23.65 \\
\hline Sarpa salpa & & & & & 1 & 0.02 & 11 & 0.24 & & \\
\hline Solea turbynei & 4 & 1.01 & 6 & 0.37 & 22 & 0.44 & 4 & 0.09 & 2 & 0.17 \\
\hline Syngnathus temminckii & & & 1 & 0.06 & 1 & 0.02 & & & & \\
\hline Torpedo fuscumaculata & & & & & 1 & 0.02 & & & & \\
\hline Torpedo sinuspersici & & & & & & & 1 & 0.02 & & \\
\hline Valamugil buchanani & & & 1 & 0.06 & 2 & 0.04 & 6 & 0.13 & 2 & 0.17 \\
\hline Valamugil robustus & & & 1 & 0.06 & & & 4 & 0.09 & & \\
\hline Total numbers & 396 & & 1605 & & 5007 & & 4557 & & 1163 & \\
\hline Total taxa & 24 & & 27 & & 33 & & 36 & & 22 & \\
\hline
\end{tabular}


TABLE A9

Biomass composition of fishes captured in predominantly open estuaries between Kayser's Beach and Kei Mouth on the southeast coast of South Africa, September-October 1996 ( $g$ = mass; \% = percentage contribution)

\begin{tabular}{|c|c|c|c|c|c|c|c|c|c|c|}
\hline \multirow{2}{*}{ Species } & \multicolumn{2}{|c|}{ Buffalo } & \multicolumn{2}{|c|}{ Nahoon } & \multicolumn{2}{|c|}{ Gqunube } & \multicolumn{2}{|c|}{ Kwelera } & \multicolumn{2}{|c|}{ Quko } \\
\hline & $\mathbf{g}$ & $\%$ & g & $\%$ & $\mathbf{g}$ & $\%$ & $\mathbf{g}$ & $\%$ & $\mathbf{g}$ & $\%$ \\
\hline Acanthopagrus vagus & 476.4 & 3.17 & & & & & 460.8 & 0.67 & & \\
\hline Ambassis ambassis & & & & & 3.1 & 0.01 & & & & \\
\hline Ambassis dussumieri & & & & & 39.5 & 0.07 & & & & \\
\hline Amblyrhynchotes honckenii & & & & & & & 12.4 & 0.02 & & \\
\hline Antennarias striatus & & & & & & & 1.5 & 0.00 & & \\
\hline Argyrosomus japonicus & 825.0 & 5.49 & 4360.0 & 7.76 & 4075.9 & 6.95 & 6588.3 & 9.58 & 8210.0 & 24.17 \\
\hline Atherina breviceps & 1.1 & 0.01 & 183.2 & 0.33 & 266.3 & 0.45 & 21.4 & 0.03 & & \\
\hline Caffrogobius gilchristi & 28.4 & 0.19 & 133.6 & 0.24 & 127.3 & 0.22 & 254.1 & 0.37 & 15.2 & 0.04 \\
\hline Caffrogobius nudiceps & 3.4 & 0.02 & 28.1 & 0.05 & 10.2 & 0.02 & 20.2 & 0.03 & & \\
\hline Carcharias taurus & & & 8004.0 & 14.25 & & & & & & \\
\hline Clinus superciliosus & & & 0.2 & 0.00 & 2.5 & 0.00 & & & & \\
\hline Dasyatis kuhlii & & & & & & & 2728.0 & 3.97 & & \\
\hline Diplodus capensis & 0.3 & 0.00 & 5.8 & 0.01 & 6.0 & 0.01 & 8.9 & 0.01 & & \\
\hline Diplodus hottentotus & & & & & 1.1 & 0.00 & 0.6 & 0.00 & & \\
\hline Elops machnata & 4683.0 & 31.14 & 26732.0 & 47.58 & 20289.0 & 34.60 & 7351.0 & 10.69 & 6417.0 & 18.89 \\
\hline Gaelichthys feliceps & 1749.0 & 11.63 & & & 1562.0 & 2.66 & 6752.0 & 9.82 & 3619.4 & 10.66 \\
\hline Gilchristella aestuaria & 107.5 & 0.71 & 274.8 & 0.49 & 1188.3 & 2.03 & 929.0 & 1.35 & 496.5 & 1.46 \\
\hline Glossogobius callidus & & & 38.0 & 0.07 & 237.7 & 0.41 & 131.3 & 0.19 & 38.0 & 0.11 \\
\hline Hemiramphus far & 5.7 & 0.04 & & & & & & & & \\
\hline Heteromycteris capensis & & & 3.3 & 0.01 & 1.7 & 0.00 & 0.1 & 0.00 & 4.1 & 0.01 \\
\hline Lichia amia & 1366.0 & 9.08 & & & 5690.0 & 9.70 & 5935.0 & 8.63 & 388.0 & 1.14 \\
\hline Lithognathus lithognathus & 828.7 & 5.51 & 46.3 & 0.08 & 11.2 & 0.02 & 1074.2 & 1.56 & 308.0 & 0.91 \\
\hline Liza dumerili & 1512.7 & 10.06 & 2186.9 & 3.89 & 7422.0 & 12.66 & 5749.9 & 8.36 & 184.7 & 0.54 \\
\hline Liza macrolepis & & & & & 13.6 & 0.02 & 359.6 & 0.52 & 24.1 & 0.07 \\
\hline Liza richardsonii & 365.3 & 2.43 & 2183.1 & 3.89 & 1388.5 & 2.37 & 5307.0 & 7.72 & 7254.0 & 21.36 \\
\hline Liza tricuspidens & 282.0 & 1.87 & 6495.0 & 11.56 & 5697.8 & 9.72 & 7917.8 & 11.51 & 2206.6 & 6.50 \\
\hline Monodactylus falciformis & 211.0 & 1.40 & 64.0 & 0.11 & 225.9 & 0.39 & 918.0 & 1.33 & 64.7 & 0.19 \\
\hline Mugil cephalus & & & 1283.1 & 2.28 & 2742.9 & 4.68 & 3044.1 & 4.43 & 680.6 & 2.00 \\
\hline Mugilidae & 1.9 & 0.01 & 2.1 & 0.00 & 8.0 & 0.01 & 11.6 & 0.02 & 0.7 & 0.00 \\
\hline Myliobatis aquila & 205.0 & 1.36 & & & & & & & & \\
\hline Myxus capensis & & & 10.4 & 0.02 & & & 1.0 & 0.00 & 203.9 & 0.60 \\
\hline Platycephalus indicus & 109.9 & 0.73 & & & & & & & & \\
\hline Pomadasys commersonnii & & & 774.4 & 1.38 & 104.6 & 0.18 & 2646.1 & 3.85 & 703.1 & 2.07 \\
\hline Pomadasys olivaceus & 6.3 & 0.04 & 129.6 & 0.23 & 75.9 & 0.13 & 39.8 & 0.06 & & \\
\hline Pomatomus saltatrix & 1316.4 & 8.75 & & & 1242.0 & 2.12 & 753.0 & 1.09 & & \\
\hline Psammogobius knysnaensis & 3.8 & 0.03 & 8.6 & 0.02 & 15.1 & 0.03 & 12.8 & 0.02 & 7.0 & 0.02 \\
\hline Raja miraletus & & & & & & & 11.1 & 0.02 & & \\
\hline Rhabdosargus holubi & 945.9 & 6.29 & 3199.3 & 5.69 & 4623.4 & 7.88 & 5145.4 & 7.48 & 1680.6 & 4.95 \\
\hline Sarpa salpa & & & & & 0.2 & 0.00 & 901.0 & 1.31 & & \\
\hline Solea turbynei & 5.4 & 0.04 & 7.0 & 0.01 & 25.5 & 0.04 & 6.9 & 0.01 & 8.4 & 0.02 \\
\hline Syngnathus temminckii & & & 0.1 & 0.00 & 0.4 & 0.00 & & & & \\
\hline Torpedo fuscumaculata & & & & & 265.8 & 0.45 & & & & \\
\hline Torpedo sinuspersici & & & & & & & 43.5 & 0.06 & & \\
\hline Valamugil buchanani & & & 24.9 & 0.04 & 1283.7 & 2.19 & 3628.3 & 5.28 & 1447.0 & 4.26 \\
\hline Valamugil robustus & & & 6.4 & 0.01 & & & 12.1 & 0.02 & & \\
\hline Total numbers & 15040.0 & & 56184.2 & & 58646.9 & & 68777.6 & & 33961.5 & \\
\hline Total taxa & 24 & & 27 & & 33 & & 36 & & 22 & \\
\hline
\end{tabular}

